\title{
Kajian Webblog sebagai Desentralisasi Informasi Ditinjau dari Perspektif Komunikasi Massa
}

\author{
Dewi Novianti dan Wahyuni Choiriyati \\ Program Studi Ilmu Komunikasi Fakultas Ilmu Sosial dan Ilmu Politik \\ Universitas Pembangunan Nasional "Veteran”Yogyakarta Jl. Babarsari no 2 Yogyakarta 55281 \\ Telp 0274-485268, Fax.0274-487147, e-mail: dewinovianti_upn@yahoo.co.id
}

\begin{abstract}
Abstrak
Internet as an interactive medium has the ability in connecting, interacting and communicating a wide range of information across the country has made the Internet as the modern mass communication media. Communications perspective has penetrated internet as part of media studies. The term demystification has been used to describe the gap the position the internet has within the context of mass communication medium. Based on this issue, the research reveals the extent to which the role of weblogs in mass communication studies perspective with an approach of mass communication theory. Specifically, the purposes of this study were to describe cyber webblog as a multi-media messaging, formulate the existence of Webblog within mass communication perspective, and understanding the existence of Webblog in the decentralization of information. This study used framing analysis of Robert $N$. Entman. The findings show that Weblog meets several requirements that support the creation of media freedom in the realm of mass communication system characterized by the presence of autonomous media ownership, personal (non-institutional), practical, and free. Also, it uses Voluntary Posting messages operating structure, uncensored, doesn't need license, non-regulated media, free from routine media mechanism, no gate keeping media and originality can be maintained. Publishing system is critical, innovative, and independent. The substance of the message meets the criteria of relevance, readers meet specifications, features deeper formats, essays have a sense of human.
\end{abstract}

\begin{abstract}
Abstrak
Internet sebagai media interaktif mempunyai kemampuan dalam menghubungkan, menginteraksikan serta mengomunikasikan berbagai macam informasi di seluruh negara menjadikan internet sebagai media komunikasi massa modern. Perspektif komunikasi merambah internet sebagai kajian penelitian media. Istilah demistifikasi yaitu adanya kesenjangan posisi internet dalam konteks sebagai media komunikasi massa. Terkait dengan internet dan penggunaan webblog terus meningkat dari tahun ke tahun. Berangkat dari permasalahan tersebut, penelitian mengungkap sejauh mana peran webblog dalam perspektifkajian komunikasi massa. Secara spesifik, tujuan penelitian ini adalah mendeskripsikan webblog sebagai media cyber yang multi pesan, merumuskan keberadaan Webblog dalam perspektif komunikasi massa, mengetahui eksistensi Webblog dalam desentralisasi informasi. Penelitian ini menggunakan metode analisis framing model Robert N. Entman. Hasil penelitian menemukan bahwa Webblog ini memenuhi beberapa syarat yang menunjang terciptanya kebebasan dalam bermedia dalam ranah komunikasi massa yang ditandai dengan adanya sistem kepemilikan Media bersifat otonom, personal (non institusional), praktis, dan gratis, struktur operasional pesan bersifat voluntary posting, bebas sensor, lisensi, non regulated media, terbebas dari mekanisme media routine, tidak ada gate keeping media, dan orisinalistas bisa terjaga. Sistem publikasi bersifat kritis, inovatif, dan independen. Terakhir substansi pesan memenuhi kriteria relevansi, mencukupi spesifikasi minat pembaca, lebih mendalam dengan format feature, essay yang memiliki sense of human.
\end{abstract}

Kata kunci : webblog, blogger, demistifikasi, analisis framing 


\section{Pendahuluan}

Munculnya internet merupakan fenomena perkembangan teknologi komunikasi yang mulai dikenal publik pada awal milennium ke tiga. Internet yang merupakan singkatan Interconnection Networking sangat signifikan dengan karakter yang dimilikinya. Kemampuan dalam menghubungkan, menginteraksikan, serta mengkomunikasikan berbagai macam informasi di seluruh negara menjadikan internet sebagai media komunikasi massa modern.

Seiring dengan maraknya penggunaan internet, perspekif komunikasi merambah internet sebagai kajian penelitian media. Sering muncul istilah demistifikasi, adanya kesenjangan posisi internet dalam konteks sebagai media komunikasi massa, terlebih dalam dunia jurnalisme. Saat ini pendayagunaan teknologi internet dalam komunikasi massa telah membawa banyak perubahan fundamental pada sistem media massa konvensional. Teknologi internet yang mengandalkan sistem jaringan tidak tersentral telah membuat semua orang dengan secara interaktif mencari informasi, menyimpan, memproses, dan sekaligus mempublikasikannya. Tidak dapat dipungkiri internet menjadi sebuah kekuatan media massa modern, yang mengedepankan kebebasan, aktualitas pesan, interaktifitas, fleksibilitas, dan desentral menjadi pilar utamanya.

Internet mampu menumbuhkan kreatifitas dan kemampuan jurnalis yang memungkinkan terjadinya distribusi kesempatan bagi seseorang untuk menjadi newsmaker sekaligus editor dan publisher.

Salah satu bentuk media yang saat ini digunakan oleh pengguna internet untuk melakukan aktifitas jurnalisme secara personal adalah sarana Webblog. Webblog merupakan situs yang dikelola oleh satu orang secara individual. Umumnya terfokus pada suatu obyek atau topik tertentu, dapat berupa berita, catatan harian, daftar komentar, kumpulan link, atau diskusi yang merupakan hasil pemikiran. Merupakan hak setiap orang untuk membuat Blog dengan gaya apapun, namun tidak semua menyadari bahwa Blog yang diciptakan bisa dibaca dan diakses oleh orang lain, dari pengelolaan media yang bersifat personal ini, Weblog berkembang ke arah media publik.
Karakteristik utama dari Webblog yang membedakannya dengan bentuk Website lain adalah selalu adanya penanda tanggal dan waktu pada setiap posting yang dilakukan. Weblog di up date secara kontinyu, dimana Blogger sebagai pemiliknya bebas untuk menuliskan segala apa yang dipikirkan, dirasakan dan dialami dalam kehidupan sehari-hari, yang berkaitan dengan tema pembicaraan yang dekat dengan keseharian sampai pada topik yang lebih serius.

Fenomena Webblog saat ini mulai mendapatkan perhatian luas dari berbagai pihak, baik ahli dibidang teknologi informasi, pengamat media, pengamat komunikasi ataupun juga pengamat sosial. Hadirnya Webblog memiliki nilai penting sebagai bagian dari media komunikasi massa baru dengan karakteristik tersendiri, dibandingkan dengan bentuk media massa lainnya seperti televise, radio, surat kabar, majalah maupun film, dilihat dari sistem pengoperasian maupun tampilan fisik medianya.

Berikut adalah gambaran pengguna Webblog hasil riset Nita Yuanita. Responden terdiri dari pemilik Blog (89 persen), pembaca log rutin(tujuh persen) dan pembaca $\log$ tidak rutin (empat persen). 75 persen responden bertempat tinggal di Indonesia, yaitu di Jakarta, Bandung, Yogyakarta, Surabaya, Bogor, Depok, Pontianak, Brastagi, Temanggung, Balikpapan, Malang, Bayuwangi dan Solo. Sedangkan 25 persen responden tinggal di luar Indonesia yaitu di negara Canada (Montreal), Amerika (New York, Ohio, Austin, Cleveland), Inggris (Menchester), Australia (Sydney, Adelaide), Perancis (Nantes, Amiens), Selandia Baru (Auckland), Jerman, Belanda, Mesir (Kairo), Pantai Gading(Abidjan), Myanmar (Mandalay), Thailand (Bangkok), dan Jepang (Tokyo, Fukuoka).

Besarnya pengguna Webblog tampak pada gambar 1.1. Keinteraktifan Blog, merupakan salah satu faktor penunjang kepopulerannya. Media konvensional yang bersifat satu arah berubah bentuk menjadi tempat di mana aspirasi setiap orang mendapat tempat, walau belum tentu memiliki news value. Karakter yang dimunculkan oleh Blog adalah membalikan struktur dari media konvensional yang bersifat top down, kaku, dan cenderung menggurui. Dari sekian karakter yang nampak, Blog merupakan bagian dari evolusi 
komunitas elektronik. Mengarah pada perubahan paradigma jurnalistik secara online dengan menciptakan media yang mereka kostumisasi sendiri. Istilah kostumisasi yang dimaksud adalah, media yang lepas dari kecurigaan media sebagai bagian dari korporasi besar. Blog diibaratkan sebagai media massa modern dengan mendemonstrasikan simbol, informasi,tentang budaya interaktif yang mengakomodasi setiap opini.

Penelitian mengangkat dua alamat Webblog, yakni ath-tahriq.blogspot.com dan subhanafifi.blogspot.com. Dua alamat Weblog ini cukup representative untuk diteliti, di mana kedua Blogger aktif menulis Blog secara teratur. Pengamatan terhadap lingkungan, pengalaman baik yang dialami secara pribadi maupun orang lain, serta suara hati kedua Blogger ini tertuang dalam tulisan-tulisan di alamat Webblog mereka. Meskipun ditulis dan diedit secara personal, Webblog mampu mengajak pembacanya untuk mengetahui informasi yang disajikan oleh Blogger, bahkan mampu menggerakkan massa untuk bersikap. Sifat audience dari Weblog hampir sama dengan media massa pada umumnya, seperti heterogen, anonim, tersebar, tidak mengenal batas geografi-kultural, hanya saja sifatnya yang virtual.

Berangkat dari masalah tersebut maka penelitian ini mendeskripsikan karakter Webblog sebagai referensi media komunikasi. Sehingga gambaran eksistensi dan pendayagunaan Webblog sebagai bagian dari refleksi kajian Komunikasi Massa menjadi lebih jelas.

Penelitian ini dilakukan untuk menjawab pertanyaan;

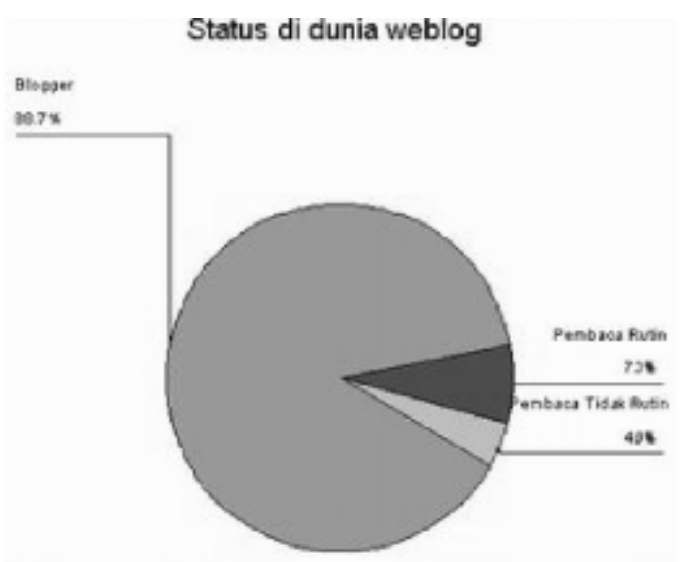

"Bagaimana eksistensi Webblog sebagai desentralisasi informasi ditinjau dari perspektif komunikasi massa?".

Kerangka berfikir yang mendasari penelitian fenomena Webblog berkenaan dengan esensi aktifitas komunikasi massa yang berkaitan dengan gatekeepers, regulator, media, dan filter sebelum pesan akhirnya sampai kepada audience. Dapat digarisbawahi, media massa mempunyai peran yang sangat signifikan dalam komunikasi massa.

Pemanfaatan Webblog yang telah merambah pada kawasan media massa sedikit banyak menimbulkan deviasi terhadap pemahaman konseptual komunikasi massa. Beberapa aspek yang ditunjukkan menjadikan deviasi tersebut meliputi, komunikator dalam konteks Webblog bukan institutional media, namun pengelola personal yang sangat individual. Komunikator Webblog merupakan perseorangan dengan karakter personal, sebuah komunitas, suatu perusahaan, organisasi, klub dan sebagainya. Di dalam dunia Webblog tidak muncul batasan tertentu yang mensyaratkan ketrampilan dan skill khusus di bidang jurnalistik untuk memasuki dunia Webblog. Tampilan dan Webblog menjadi fleksibel untuk bisa dipersonalisasikan sesuai dengan keinginan Blogger. Keinginan kearah desentralisasi informasi menjadi bukan dominasi gatekeeper, regulator ataupun bentuk-bentuk filter dalam memformulasikan pesan.

Kekuatan yang dimunculkan oleh internet dalam meretas aktualitas menjadikan gaya Blog memiliki kekuatan informasi yang terdistribusi

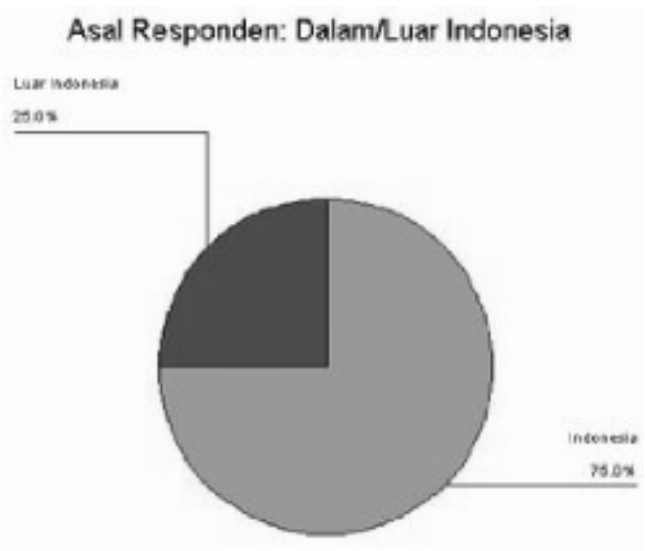

Gambar 1. Status di Dunia Webblog dan Asal Responden : Dalam/Luar Indonesia Sumber http//www.yuanita blog. Survey,html,01 Maret 2007 
dengan Jurnalisme Blog. Jurnalisme media online menghadirkan komentar-komentar yang tidak terframing, kemudian akan mengingatkan betapa media konvensional seringkali terinfeksi oleh vested-interest dalam membuat berita. Blog-blog yang muncul memiliki kecenderungan memilih topik berita dan artikel serta website yang sesuai dengan preferensi personal Blogger-nya. Hal tersebut mengesankan bahwa pesan telah di filter, telah dijelajahi terlebih dahulu (presurfed) oleh para Blogger dan orang lain tinggal menikmati apa yang telah ditampilkan oleh Blogger sesuai dengan minat inormasi yang dicari (personal preference). Blogger memilihkan link-link pada Website dan berita yang paling aneh, spektakuler, hingga paling lengkap atau tidak lengkap dari Web. Jon Katz menyebutnya Blog, telah melalui tahap Filtered News. Blog sebagai saringan The Web, dianggap mampu menyelamatkan komunikan dari kekacauan atau sentralisasi informasi online yang terjadi pada internet, terlebih pada media massa konvensional.

Sifat personal yang ditampilkan, cenderung menjadikan Webblog mempunyai audience heterogen. Meskipun kuantitas audience bersifat tentatif, yang disebabkan oleh karakter dan kualitas informasi dalam Webblog. Namun Webblog, memungkinkan terjadinya kontak secara interaktif yang bersifat personal dengan audiencenya. Hal ini mengarahkan Webblog menjadi sebuah generasi dalam media massa yang sangat familiar dengan audience-nya. Informasi yang diterima pembaca tanpa melalui perantara, unsur originalitas pesan tetap terjaga,hingga posting di Webblog-nya tanpa campur tangan pihak lain. Komunikator dalam distribusi informasi, tidak perlu risau dengan respon pembaca. Publikasi informasi menjadi tidak melulu berkaitan dengan hal-hal yang semata merupakan kebutuhan publik saja atau mengikuti selera pasar. Blogger mempunyai otonomi yang lebih luas atas pemanfaatan Webblog-nya. Blogger juga bisa mempublikasikan informasi yang sengaja dibiaskan, ditutupi atau hidden information oleh media mainstream.

\section{Teori Peran Mediasi}

Merujuk pada teoriperan mediasi, media massa diletakkan sebagai jendela, dan manusia diibaratkan the extention of man, yang terjadi dalam realitas sosial kehidupan. Media menjadi cermin terhadap peristiwa dan pengalaman hidup di sekitarnya. Media dijadikan guider atau interpreter, atas apa yang dipertanyakan publik. Media menjadi suatu forum atau platform untuk menyampaikan gagasan kepada masyarakat. Sebagai interlocutor yang tidak terbatas memberikan informasi, namun juga merespon atas berbagai kebingungan masyarakat.

Sehubungan dengan peran media massa tersebut, maka pendayagunaan Weblog sebagai komoditas media massa menjadi lebih maksimal. Bila direfleksikan sebagai window atau cermin, platform, guider atau interpreter, keberadaan Webblog mampu menghasilkan ide, inspirasi tentang banyak hal. Sedangkan apabila diasumsikan sebagai gatekeeper, maka terhadap informasi yang dimuat dalam Webblog diakses berdasarkan minat ketertarikan Blogger dari pemilik Webblog tersebut, karenanya Webblog umumnya bersifat khusus tentang hal-hal tertentu. Kondisinya menjadi sangat terspesialisasi karena muncul Webblog-Webblog, yang mendiskusikan berbagai informasi.

\section{Teori Kebebasan Media}

Berdasarkan teori kebebasan media, terdapat dua aspek yang utama, yaitu: media memberikan kesempatan pada beragam gagasan, suara , juga pendapat serta memberikan respon. Aspek tersebut, mendasari pula konsepsi tentang kebebasan media, yang mengedepankan independensi, kesetaraan beragumentasi, kesejajaran, kreatiitas, originalitas, dan kemajemukan. Gambar berikut ini menunjukkan tingkat interaktifitas Blogger yang antusias terhadap informasi di tampilan Webblog. Berdasarkah hasil survey Nita Yuanita.

Apa yang dilakukan ketika mendatangi Blog baru? Hampir semua responden menyatakan akan berusaha mengenal Blog baru tanpa langsung meninggalkan, meskipun kedatangannya tidak disengaja. Selanjutnya pengenalan sekilas suasana Blog dari kombinasi pemilik Blog, desain dan posting. Dari sini 92 persen melanjutkan dengan membaca posting-posting yang ada, meskipun hanya 61 persen diantara pembaca yang 
menuliskan komentar atas posting tersebut, sisanya memilih untuk tidak berkomentar. Sisa enam persen responden yang tidak membaca, hanya meninggalkan ‘jejak' sebagai tanda kehadiran atau sapaan pada pemilik Blog melalui Tagboard atau Guestbook.

Fungsi media massa adalah meretas kebisuan pada sentralisasi informasi, maka eksistensi Webblog memberikan lebih banyak ruang yang membuka keberagaman interpretasi sebuah peristiwa. Publik tidak menjadi dominasi informasi yang diagendakan oleh media dalam korporasi bisnis media, tidak menjadi sebuah nilai mutlak. Konsepsi kesetaraan, diasumsikan menggunakan banyak standar terhadap suatu peristiwa. Realitas ini tercermin, karena setiap Bloggermemiliki keahlian, perspektif, refleksi serta pola pikir yang beragam dalam memaknai peristiwa.

Dari uraian mengenai wacana desentralisasi informasi, maka aspek kebebasan terefleksi secara aktual melalui Webblog. Refleksi yang nampak adalah tidak adanya motif represi kelompok pengusaha atau mayoritas, sehingga Webblog mencerminkan sebagai media mejemuk yang sarat ide dan gagasan yang selalu menginginkan respon. Keterbukaan akses yang sangat luas bagi setiap orang, meliputi berbagai kalangan, latar belakang dan bidang ilmu, mengkondisikan atmosfer Webblog menampung beragam perbedaan, beragam inovasi, dan kreatifitas dengan prinsip keterbukaan.

Filosofi atas mekanisme desentralisasi informasi yang berujung pada upaya menciptakan kebebasan media, memiliki dampak positif pada kebutuhan sehari-hari dari beragam institusi sosial. Sebagai akibat dari munculnya aktifitas pers yang independen maka sistuasi ini menjadi semacam prekondisi dan evaluasi peran-peran pengawasan sebagai bentuk kewaspadaan publik, sehubungan dengan pemilik kekuatan-kekuatan media, pengendali kebijakan dalam hal ini pemerintah dan korporasi media yang saling berafiliasi.

Manfaat yang dirasakan oleh publik atas adanya kebebasan media adalah terciptanya pengawasan yang seksama oleh publik secara sistematis dan independen terhadap pihak pemilik kekuatan. Merujuk pada konsepsi McQuails bahwa situasi tersebut akan membiasakan suplai- suplai informasi yang terpercaya yang seringkali berkenaan dengan fungsi pengawasan dan kritik atas pers dalam hal ini dilakukan oleh komunitas masyarakat yang tidak memiliki afiliasi media. Lebih lanjut McQuails mengatakan bahwa munculnya akselerasi informasi yang progresif dalam masyarakat mengakibatkan hal-hal berikut ini; (1) Menciptakan situlasi atas terbangunya sisitem demokrasi sebuah negara dalam kehidupan sosial yang terbuka; (2) Terdapa kesempatan dalam mengekspresikan kepercayaan dan pandanganpandangan mengenai fenomena kehidupan sosial; (3) Terlaksananya pembaharuan dan perubahan dalam struktur masyarakat secara berkelanjutan; (4) Peningkatan jumlah atas variasi kebebasan dalam informasi melalui berbagai aspek yang dapat dilakukan oleh publik (McQuails, 2000:168).

Perdebatan atas media baru melalui teknologi informasi dengan moda internet merupakan refleksi atas prinsip kebebasan informasi dalam kajian komunikasi massa. Kehadiran Weblog dengan beragam versi independensinya (motif, bentuk, gaya penulisan, waktu edar, dan sebagainya) menjadikan Weblog sebagai media yang memiliki kekuatan dalam penyebaran informasi. Keterbukaan atas sifat jamak Weblog menjadi sebuah media yang memiliki akses seluas-luasnya bagi semua orang dari berbagai kalangan, berbagai bidang ilmu dan menampung aspek orisinalitas dalam wadah yang terbuka.

Diskusi mengenai kebebasan media memiliki relasi kuat dengan konsep kesetaraan media. Kesetaraan dalam aktifitas media massa, secara spesifik berkenaan dengan beberapa aspek. Berkaitan dengan suatu prinsip maka kesetaraan mendasari beberapa ekspektasi normatif yang ditujukan ke media massa. Sehubungan dengan komunikasi dan politik, kesetaraan mengharuskan adanya perhatian atau kelebihan tertentu yang berada pada pemegang kekuasaan, maka akses terhadap media diberikan kepada pihak oposisi dan pendapat-pendapat yang bertentangan atau kontroversial dengan suara mayoritas.

Merujuk pada nurriest.blogdrive dalam hal klien bisnis dari institusi media, kesetaraan memerlukan dasar kesamaan perlakuan (kesamaan atas kondisi) bagi para pengiklan sehingga prinsip umum pasar dapat dioperasikan secara bebas dan kesetaraan dapat mendukung terwujudnya 

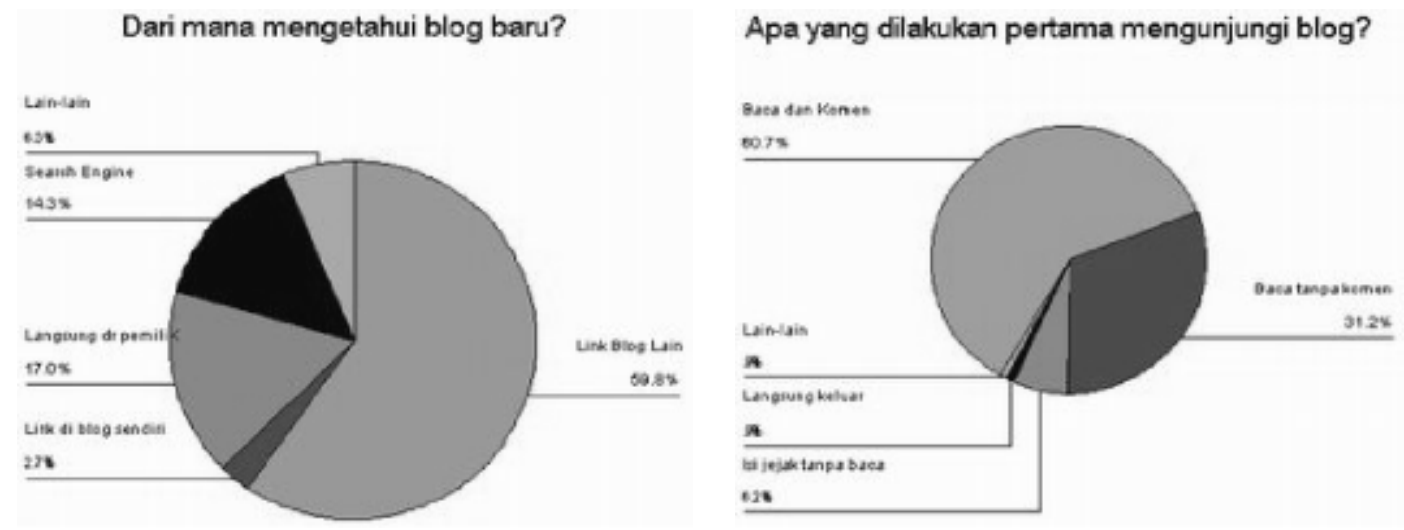

Gambar 2. Dari Mana Mengetahui Blog Baru dan Apa yang dilakukan Pertama Mengunjungi Blog (Sumber : http//www.yuanita_blog.survey.html,akses : 28 Februari 2007)

berbagai ekspektasi publik tentang keadilan akses. Hal tersebut karena kesetaraan menuntut kenihilan diskriminasi atau bias pada jumlah dan bentuk.

Mc Quails menjelaskan bila konsep ini kita terapkan dalam logika media maka secara luas dapat digunakan baik oleh pengirim ataupun penerima informasi sehingga didapatkan keragaman bentuk perspektif informasi. Kesetaraan juga menyentuh masalah objektifitas yang berkaitan dengan nilai-nilai independensi, sisi profesionalisme dan otonomi sepenuhnya atas hak memperoleh informasibagi setiap individu. Prinsip-prinsip kesetaraan media dijelaskan melalui skema berikut;

Upaya membangun kesetaraan dalam praktek media massa sangat bergantung pada tingkat pertumbuhan sosial ekonomi masyarakat, serta kapasitas sistem dari masing-masing kepemilikan media.

Stuart dalam buku Jornalism On The Web menguraikan mengenai "Citizen Produced Coverage" bahwa selepas peristiwa 11 September di Amerika, ribuan website-website mengalami perubahan penampilan secara cepat. Banyak orang-orang awam yang memaksa mengirimkan kesak-sian mereka atas tragedi 11 September, berupa foto, interpretasi dan analsisi atas kejadian itu. Terminologi peliputan masyarakat untuk mendefinisikan produksi reportase oleh masyarakat awam yang bersifat amatir, berupa reportase instan, kolumnis opini dan para jurnalis foto amatir. Kontribusi aktifitas jurnalis masyarakat ini memiliki justifikasi atas persoalan dalam bingkai yang mereka pahami. Mereka melakukan proses distribusi pesan melalui email tanpa menggunakan nama dan identitas yang jelas.

Stuart menegaskan bahwa situasi inilah yang membuat perbedaan mencolok antara peliputan masyarakat dengan reportase yang menjadi mainstream dalam konteks jurnalistik.

Worthy of particular attention here was the role played by Weblog in helping to facilitate the circulation of this form coverage. A Weblog is a personal "log" or journal of the web, usually updated on a daily basis, and typically thick with clickable hyperlinks to other items availableelsewhere on the Web that the author (called aWeblloger", or Blogger" for short) consider worth viewing (Stuart, 2004: 179).

Sola Pool (McQuail, 2000:137) lebih lanjut menjelaskan bahwa image tentang kebebesan yang melekat pada internet lebih berkenaan dengan kapasitas kecepatannya dan dengan kurang atau Iebih, tidak adanya struktur, organisasi dan managemen pengoperasiannya, terutama pada masa-masa awal media tersebut digunakan secara bebas bagi semua pengguna (nurriest.blogdrive).

The system had an in-built resistance to attempts control or manage it. It appeared not to be owned managed by anyone in particular, to belong to no of jurisdiction. In practice, its content and the use of it were not easy to control or sanction, even jurisdiction could be established. Relative to most media, the internet remains free and unregulated .

Sehubungan dengan retorika kehadiran media baru memungkinkan media elektronik da- 


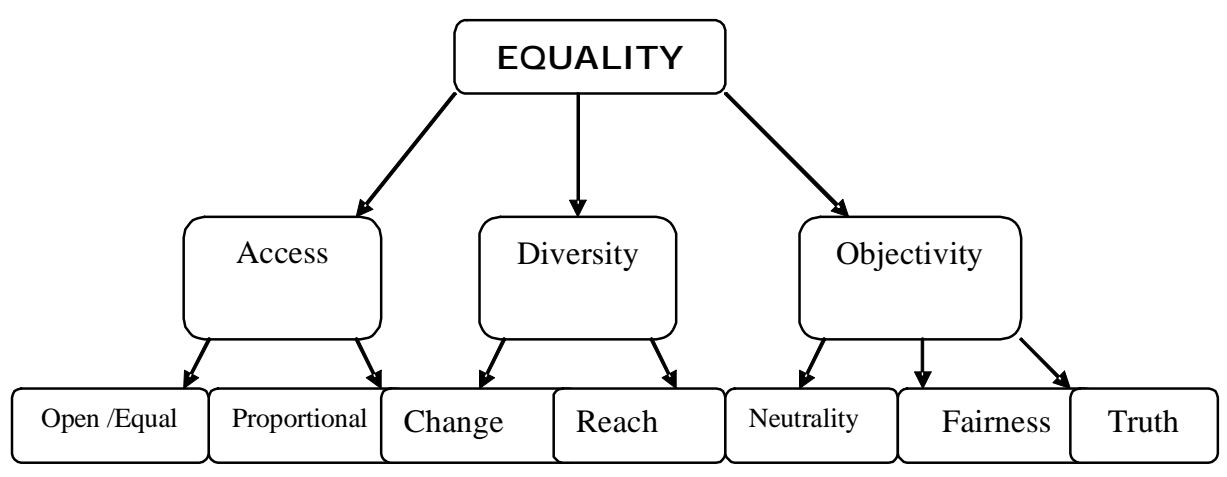

Gambar 3. Prinsip-Prinsip Kesetaraan Media

Sumber : (McQuails, 2000:169)

pat membantu untuk mewujudkan manfaat yang setara (equal) seperti halnya masyarakat dalam era liberalisasi informasi. Internet memberikan keuntungan terbesar pada akses bagi semua pengguna untuk berbicara tanpa melalui mediasi oleh kepentingan-kepentingan yang mempunyai kekuatan seperti tercermin dalam kontrol dan tarik menarik kekuatan dari media cetak dan elektronik.

\section{Metode Penelitian}

Secara spesifik, tujuan penelitian ini adalah mendeskripsikan Webblog sebagai media cyber yang multi pesan. Merumuskan keberadaan Webblog dalam perspektif komunikasi massa. Mengetahui eksistensi Webblog dalam desentralisasi informasi. Manfaat penelitian ini diharapkan mampu memberikan khasanah baru pada kajian Webblog sebagai bagian media cyber.

Penelitian ini dapat diklasifikasikan dalam penelitian deskriptif, yaitu menjelaskan fenomena pemanfaatan Webblog dalam kajian Webblog sebagai desentralisasi media informasi. Sekaligus penelitian ini akan memaparkan paradigma baru dalam perspektif komunikasi massa dengan kajian pemanfaatan Webblog.

Objek dalam penelitian ini adalah Webblog-Webblog yang aktif di posting secara teratur oleh para Blogger (pemilik Blog) selama tiga sampai empat bulan terakhir. Kemudian artikel dipilih secara acak. Fokus dari objek penelitian ini adalah analisis terhadap isi posting dalam $\mathrm{Web}$ blog-Webblog tersebut atau aspek-aspek lain yang menunjang data penelitian.

Jenis data yang digunakan; (a) Data primer, yaitu data yang diperoleh secara langsung dari informan yang dalam hal ini adalah komunitas Blogger. Disini peneliti mengambil dua alamat Webblog, yakni ath-tahriq.blogspot.com dan subhanafifi.blogspot.com. Masing-masing Blog diambil artikel yang diposting selama 3-4 bulan terakhir dari Blog tersebut. Kemudian setiap bulannya diambil secara acak satu sampai dengan dua artikel. Artikel atau tulisan tersebut dianalisis dengan menggunakan metode framing analisys; (b) Data sekunder, yaitu data yang digunakan untuk melengkapi data primer. Berupa data yang telah didokumentasikan dan data-data yang mendukung lainnya seperti buku-buku, berita diberbagai media massa terkait masalah Blog.

Metode pengumpulan data yang dipakai dalam penelitian ini adalah sebagai berikut; (a) Pertama data dikumpulkan dari alamat Webblog yang telah ditentukan. Kemudian peneliti memilih artikel Blog yang telah diposting oleh Blogger. Artikel yang telah dipilih dianalisis dengan menggunakan metode framing analisys. Selanjutnya untuk mengetahui karakter artikel lebih dalam peneliti melakukan wawancara kepada pemilik Blog yang telah dipilih tadi; (b) Studi Pustaka. Dalam pengumpulan data-data dalam penelitian ini, penelitimenggunakan berbagai macam sumber data dan teori yang diperoleh dari buku-buku, majalah, surat kabar, makalah, seminar, internet, komunitas Blogger dan berbagai informasi sebagai penunjang penelitian.

Analisa dalam penelitian ini menggunakan pendekatan wacana dengan menganalisis representasi teks dan menyusun analogi terhadap data-data tekstual secara komprehensif. Teks akan dianalisis dengan menggunakan analisis framing model Robert N. Entman. Analisis framing me- 
rupakan sebuah metode penelitian mengenai media massa yang dasar penelitiannya berasal dari teori konstruksi realitas sosial. Dalam teori ini dipaparkan bahwa relaitas yang dilihat dan dibaca, di media massa tersebut bukan merupakan realitas sesungguhnya, melainkan sebuah proses konstruksi dari media-media yang bersangkutan (Herman dan Nurdiansa, 2010:156).

Robert N. Entman berasumsi bahwa framing digunakan untuk menggambarkan proses seleksi dan menonjolkan aspek tertentu dari realitas media. Framing memberi tekanan lebih pada bagaimana teks komunikasi ditampilkan dan bagian mana yang ditonjolkan atau dianggap penting oleh pembuat teks. Framing dibagi dalam dua dimensibesar, yaitu seleksi isu dan penekanan atau penonjolan aspek-aspek tertentu dari realitas atau isu (Entman, 1993:53). Entman membagi konsep framing ke dalam empat item, yang terdiri dari pemberian definisi (define problem), penjelasan (diagnose causes), evaluasi (make moral judgement) dan rekomendasi (treatment recomendation) dalam suatu wacana untuk menekankan kerangka berfikir tertentu terhadap peristiwa yang diwacanakan.

Analisis jenjang teks dalam penelitian ini menggunakan analisis framing model Robert $\mathrm{N}$. Entman, seorang ahli yang meletakkan dasar-dasar analisis framing untuk studi isi media. Menurut Entman, framing pada dasarnya merujuk pada pemberian definisi, penjelasan evaluasi, dan rekomendasi dalam suatu wacana untuk menekankan kerangka berfikir tertentu terhadap peristiwa yang diwacanakan. Secara ringkas digambarkan sebagai berikut;

Framing yang berbeda akan menghasilkan berita yang berbeda pula apabila wartawan memiliki frame yang berbeda dalam memandang suatu peristiwa dan menuliskan pandangannya itu ke dalam sebuah berita.

Selanjutnya hasil yang didapat secara menyeluruh, dipergunakan untuk merumuskan refleksi pesan secara hermeneutika. Untuk menguraikan teks dilaksanakan melalui tiga tingkatan. Petama, menganalisis substansi pesan dari isi posting maupun berbagai karakteristik yang muncul dalam Webblog. Kedua, mencermati dan menguraikan fenomena desentralisasi pesan dengan meluaskan pemanfaatan Webblog dibandingkan dengan formulasi pesan oleh media massa konvensional. Ketiga, menguraikan dan menjelaskan motivasi komunitas Blogge untuk merumuskan nilai-nilai yang mendasari personal Blogging.

Diharapkan dari tiga tahapan tersebut, dihasilkan rumusan yang merupakan relasi munculnya desentralisasi media informasi dalam Jurnalisme.

\section{Hasil Penelitian dan Pembahasan}

Peneliti membagi analisis dalam matrik yang memudahkan untuk mengetahui teknik dan proses analisis di setiap levelnya, sebagai berikut; skema struktur, metode dan unit analisis dalam penelitian desentralisasi jurnalisme melalui medium Blog.

Analisis jenjang teks, peneliti membagi analisis sebagai berikut; (1) Pemahaman Blogger untuk memilih medium Blog sebagai media ekspresi. (2) Mekanisme Blogger dalam up dating pesan (sirkulasi posting) dan aktualitas topik terkait penonjolan isu artikel; (3) Aktifitas Blogger sebagai media refleksi personal.

Ketiga level analisis tersebut akan dikupas melalui analisis framing model Robert N. Entman sebagai berikut; (1) Pemahaman Blogger untuk memilih medium Blog sebagai media ekspresi level define problem; (a) Penerbitan aththoriq. blogspot.com dilakukan sejak tanggal 23 Juni 2006. Blog ini memiliki judul (title atau tag line) Speaking With Life...

Dari tiga bulan pengamatan beberapa posting maka diperoleh karakter posting sebagai berikut; Melalui pengamatan dimulai sejak bulan Juli, September hingga Oktober maka, Blog ini memiliki karakter media ekspresi Blogger. Tercermin dari beberapa posting artikel bahasa yang digunakan bersifat informal, berupa kritik, fenomenologi perjalanan sekaligus curahan perasaan dari Blogger. Ditandai dengan tag (grup atau rubrik) berupa kolom "shoutbox" yang memungkinkan relasi komunitas Blogger terlibat langsung dengan memberikan komentar seputar artikel yang diposting, dapat dilihat pada;

ShoutBox!

View shoutbox 
http://www.shoutmix.com

Sample analisa teks Posting Friday, September 19, 2008

Terhenyak....

Menyambung soal cinta...

Aku terhenyak.

Hahaha...

Kok bisa begini ya...

Sungguh sial!

Cinta yang kubangun berbulan-bulan pupus dalam sekian menit.

Harapan-harapan itu mulai meluruh dan untuk merekatkannya aku tak tega.

Maka benarlah apa katamu Ren...

Cinta harus memilih bukan?

Ya, memilih dan memutuskan kapan pun kau mau dan suka.

Aku terhenyak ketika semuanya tak seperti yang kuduga, ketika yang ada hanya obrolan-obrolan kosong dan tak berarti, dan bahkan membuatku perlu berkata,

"Hey! Apa yang terjadi dengan dirimu? Sudah terlalu jauh kau melangkah, dan kau lupa untuk berbalik arah.

Menjadi apakah dirimu sekarang?

Kau menjadi sesuatu yang tak berarti, dan kau merindukan masa-masamu dalam romantisisme dengan mengucap-ngucapnya seperti mantra yang akan mengembalikan dirimu pada masa itu. Pada masa ketika dirimu yang penuh kejayaan.

Dan sekarang semua itu pupus bahkan tak meninggalkan jejak tentang siapa dirimu.

Bukankah itu menyedihkan Cinta?
Aku ingin merangkulmu, tapi aku ragu..."

Aku katakan cinta, kau perlu seorang teman baik dan teman yang cerdas yang akan mengembalikan masa lalumu lagi.

Lalu kau puas dengan itu.

Karena kau sekarang berada dalam pusaran orang-orang yang tak bernyali dan menunggu si Godot datang dan membiarkan dirimu berenang pada lumpur yg memupuskan warna kulitmu, sehingga tak ada bedanya antara kau dan mereka.

Artikel tersebut merupakan ekspresi kegelisahan Blogger (penulis) bernama Najmah. Sebagai penulis ia berusaha untuk mengungkapkan luapan-luapan atas perasaannya terkait cinta, dari beberapa posting artikel yang ingin kita lihat Najmah sebagai Blogger terlepas dari latar belakangnya sebagai sarjana S1 bahasa Inggris Universitas Padjajaran Bandung merasa perlu menyapa seseorang sebagai cinta. Cinta diasosikan secara inherent pada sosok seorang gadis, bukan "cinta" mewakili pada sebuah perasaan saja, namun dalam posting artikel bulan berikutnya, Najmah lebih menempatkan cinta sebagai atmosfer kehidupan yang dia dapatkan dalam sebuah rumah. Dari tiga bulan posting yang selalu dikirim oleh Najmah, dapat dilihat bahwa Blog dikondisikan Najmah sebagai bagian media relasi untuk evaluasi diri. Najmah selalu melihat kekuatan evalusi dari sesama Blogger melalui kolom Shoutbox. Dari awal terciptanya $B \log$ ini, Najmah melihat kecenderungan bahasanya dipengaruhi oleh kekuatan sastra, meskipun harapan atas forum Blog-nya adalah media relasi untuk menjalin

Tabel 1. Perangkat Framing Entman

\begin{tabular}{ll}
\hline Define Problems & Bagaimana suatu peristiwa dilihat? \\
& Sebagai apa? Atau sebagai masalah apa? \\
\hline Diagnose Cause & Peristiwa itu dilihat disebabkan oleh apa? \\
& Apa yang dianggap sebagai faktor \\
& penyebab suatu masalah? Siapa aktor yang \\
& dianggap sebagai penyebab masalah? \\
Make M oral Judgement & Nilai moral apa yang disajikan untuk \\
& menjelaskan masalah? \\
& Nilai moral apa yang digunakan untuk \\
& melegitimasi dan mendeligitimasi suatu \\
& tindakan \\
Treatment Recomendation & Penyelesaian apa yang ditawarkan untuk \\
mengatasi masalah/isu? Jalan apa yang & harus ditempuh untuk mengatasi \\
& masalah? \\
\hline
\end{tabular}

(Sumber: Eriyanto,2002:188-189) 
kedekatan dengan sesama Blogger. Banyak komentar yang terkait bahasa sastrawi Najmah, sulit dimaknai secara harafiah oleh kolega Bloggernya. Hal ini disadari Najmah ketika dirinya telah melakukan evaluasi melalui teks yang diposting sejak dua tahun lalu. Karenanya Blog ini terkesan memiliki ranah privat di bandingkan ruang publik atas sisi keilmuan Najmah yang selalu ingin dia sampaikan kepada Blogger lain. Dengan dasar ini Najmah berupaya menyampaikan pendekatan ilmiah atas pemikirannya melalui situs Multiply yang mengadopsi gaya Blog sebagai media aktualisasi yang lebih saintifik. Profil Multiply Najmah dapat di link pada alamat Rusyda Fauzanah. Berikut ini karakter representasi Najmah dalam format Multiply;

\section{REPRESENTASI KEBIJAKAN}

PUBLIK DALAM

Jun 17, '08 1:36 AM PENGOPERASIAN BUSWAY for everyone OLEH PEMERINTAH DKI

Transportasi umum merupakan salah satu bentuk pelayanan yang menjadi kewajiban pemerintah dalam memenuhi kebutuhan mobilisasi masyarakat. Bentuk implementasi konkrit kebijakan baru pemerintah DKI dalam transportasi umum perkotaan sebagai upaya mengatasi kemacetan dan mereformasi transportasi umum di Jakarta adalah pengoperasian jalur khusus bus (busway).

Keberadaan busway sebagai pengejawantahan kebijakan publik tidak lepas dari representasi sejarah perkembangan model birokrasi pemerintah. Hal ini diangkat karena pada realitasnya keberadaan busway menuai banyak kontroversi di masyarakat yaitu dari sisi ketidaksesuaian konsep awal (konsep ideal) busway dengan penerapan di lapangan. Untuk mengkaji busway sebagai salah satu studi kasus pelayanan publik maka hal ini tidak bisa dilepaskan dari aspek-aspek yang melingkupinya mulai dari apa itu kebijakan publik dan sejarah birokrasi kebijakan publik di Indonesia; konsep representasi sosial dan prosesnya; serta fakta objek yang dikaji yaitu transportasi umum Busway.

\section{Level Diagnoses Causes}

Besar kemungkinan karakter Najmah terwakili dalam dua Blog-nya (satu di situs multi- ply). Maka beberapa persoalan yang terkait dengan pemahaman desentralisasi informasi bagi sesama Blogger baru dapat ditemui pada situs multiply. Mengapa demikian? Blog Najmah tidak cukup mewakili bagi para pembaca untuk memahami apa yang diekspresikan Najmah karena ranahnya terlalu privat, menggunakan metafora dalam pemilihan diksi, tidak jelas apa yang ingin dikritik dari level basis persoalan, sekedar curahan pengalaman dan bukan posting yang solutif. Situs Multiply lebih menyentuh pada persoalan aktualitas. Berikut judul-judul posting dari situs Multiply Najmah; (1) Representasi Kebijakan Publik dalam Pengoperasian Busway oleh Pemda DKI JKT-Posting 17 Juni 2008, 01:35 WIB; (2) Halusinasi Anak Muda dan Industri Musik Posting 17 Juni 2008, 01: 35 WIB

Dari dua buah posting ini karakter pemikiran berupa informasi publik sangat terasa. Artikel ini mewakili kebutuhan massa akan sebuah pesan yang informatif dan bernilai. Najmah menyadari bahwa Multiply lebih kuat mewakili kemampuannya mengekpresikan gaya penulisan jurnalisme murni yang tidak berpaku pada gaya sastrawi dan memakai pakem bahasa formal.

\section{Level Make Moral Judgment}

Justifikasi pemilihan media Blog dengan melihat kemampuan menuturkan ekpresi diri seorang najmah didasari atas pertimbangan memilih media yang dianggap secara spesifik memiliki fungsi untuk meredam kekakuan untuk mengekresikan isi hati dan pikiran sementara yang bersangkutan memiliki kendala komunikasi, sehingga untuk mereduksi fase ketidakpastian dari efek personal dalam komunikasi inter personal bisa diminimalisir. Ekpresi melalui medium teknologi diyakini Najmah setidaknya memberikan keleluasaan atas sikap introvert yang seringkali menyerang ketika berhadapan dengan publik. Hal ini tercermin dari beberapa judul posting yang merefleksikan guratan pengalaman dan keinginan berbagi cerita dengan publik melalui pengalaman pribadinya. Contoh dari posting bulan Juni ditemukan bahwa Najmah memiliki kecenderungan mencurahkan isi hati dengan gaya penulisan feature yang memiliki sisi human interest sangat kental. 
Monday, June 16, 2008

Mamaku berkata, "Jangan Pernah mengejar Kesempurnaan!"

Minggu pagi kemarin terasa menenangkan. Mmhh..miss u Mom. Terimakasih untuk telfonnya.

Mama bilang, "Jangan pernah mencari kesempurnaan karena kau tak akan mendapatkannya." Itulah kata-kata yang menyentakku dan kemudian aku merenung sesaat. Ya Ma, mungkin aku tidak akan pernah mendapatkannya, karena kesempurnaan itu tak ada. Yang ada hanyalah keinginan dan harapan untuk menjadi dan mendekati sempurna. Hanya sebuah harapan...

Karena kita semua tak akan pernah sampai di sana Nak. Begitu kata Mama.

Yang harus kau lakukan hanyalah berusaha menjadi lebih baik dan mintalah pada Tuhan yang terbaik untukmu. Jangan pernah meminta kesempurnaan pada-Nya. Tuhan tak akan memberimu itu. Begitu kata Mama.

Tak terasa mataku memanas dan raut wajahku memerah dan butir-butir air berjatuhan. Ma, Aku ingin memelukmu. Dan menumpahkan semua rasa yang ada. Terlalu lama ruang ini memisahkan. Ah, tapi itu bukanlah sepenting ketika kau ada selalu menenangkanku. Ketika kau memberikan cinta yang selalu kutunggu dari ucapanucapanmu yang kan menguatkan kaki ini untuk tetap kokoh berdiri.

Aku selalu meminta kepada Tuhan keberkahan dan kebaikan agar selalu tercurah padamu. Karena Aku mencintaimu dan Kau mencintaku dengan bahasa yang berbeda dan tak tergantikan.

Ma, apakah kekerasanku kini adalah karena aku jauh darimu hingga dunia inilah yang mengajariku menjadi seperti ini? Dunia yang keras inilah yang membuatku menuntut segala kesempurnaan. Dan dunia yang rusak dan tidak berbelaskasihan inilah yang membuatku gigih untuk meminta kesempurnaan. Ataukah dunia inilah yang memaksaku untuk menjadi sempurna seperti yang diharapkannya padahal aku tak menginginkannya.

Aku hanya ingin sebuah kebaikan. Kebaikan yang akan menuntunku menjadi makhluk yang tahu diri. Karena aku tahu bahwa aku tak sempurna. Dan aku tahu bahwa kekurangan itu dapat diperbaiki dan masih ada waktu untuk menjadi lebih baik dan berubah. Untuk siapa pun.

Pintu itu belum tertutup, selalu ada kesempatan dan harapan untuk menjadi lebih baik... tidak untuk menjadi sempurna, karena Tuhan tak menyediakan pintu untuk itu.

Mama mengatakan kelebihan dan kekurangan adalah untuk saling melengkapi, untuk saling mengajari. Karena kau belumlah menjadi apa-apa tanpa seseorang yang melengkapimu, dan begitupun juga dia.

Nak, sekali lagi mintalah yang terbaik untuk kebaiakan dan keberkahan hidupmu, jangan pernah meminta dan mengharap kesempurnaan karena Tuhan takkan memberimu itu, karena Tuhan tak membuatkan pintu untuk kesempurnaan bagimakhluk.

Maha Suci Allah Yang Maha Besar dan Maha Sempurna!

Ya Allah, Aku meminta sesuatu yang terbaik menurut-Mu untuk kehidupanku... keluargaku dan umat Muslim semuanya.

POSTED BY NAJMAH RASYIDAH AT 1:06

AM 0 comments

Tuesday, June 10, 2008

Chasing The Perfect Thing Ever

Mom, they say the world never gives the perfect thing ever.

And I say what if we can make it?

Still, they say it won't be.

Now, the world itself shows me that she never gives the best for all.

Then, $i$ start being scared and crying all night.

Too many secrets Mom....

Too many teardrops...

And I don't wanna make the same mistake which has happened from time to time.

Just like a heritage...

And a curse.

A friend ever told me that what we can trust is only ourselves not the others.

It's horrible!

But, again half face of the world itself shows me it is true.

It hurts.

I only can expect from the other half face of it. And I won't bury that expectation forever.

Cos' Allah embraces every single thing. 
So, Mom don't cry anymore! POSTED BY NAJMAH RASYIDAH AT 3:21 AM 0 comments

July 2008 April 2008 Home

Subscribe to: Posts (Atom)

Dalam pemisahan ruang privat dan ruang publik, Blog mewakili kekuatan pemilik sebagai media ekspresi yang menawarkan ruang privat. Sementara ruang publik sangat dominant dengan kebutuhan umum atas informasi yang bukan bersifat personal sebagai contoh adalah posting dua artikel diatas. Najmah hendak menegaskan bahwa Blog menjadi medium untuk membiarkan orang membaca pengalaman hidupnya menghadapi kerasnya dunia, membagi spirit hidup dan pengalaman batin dengan pembaca lainnya.

\section{Level Treatment}

Lebih jauh Najmah ingin berbagi sebuah pengalaman dan motivasi bagi sesama Blogger atau pembaca lain (bukan Blogger) yang memiliki persoalan seputar memaknai kehidupan, sisi moral diajukan melalui tulisan Najmah yang menegaskan kata Tuhan dan optimismenya menerima pelajaran hidup karena keyakinannya atas berbuat baik mensyukuri nikmat hidup dari Nya.

Mekanisme Blogger dalam up dating pesan (posting) dan aktualitas topik terkait penonjolan isu artikel

\section{Level Define Problem}

Blog ini terbentuk pada tahun 2006, pada tahun 2008 sejak bulan Februari-Oktober telah diposting sebanyak 23 artikel. Pengamatan dimulai dari bulan Juli, September hingga Oktober, dengan distribusi posting dan judul artikel sebagai berikut: pada tampilan Blog akan kita temui tulisan angka dan penunjuk posting dengan interpretasi sebagai berikut; (a) 2008 (23) $¥$ ini menunjukkan bahwa terdapat 23 kali posting ke artikel dalam kurun waktu satu tahun terakhir; (b) Oktober (8)‡ selama bulan Oktober Blogger menyampaikan posting sebanyak delapan buah artikel. Berikut ini beberapa artikel yang ditulis berdasar judul artikel; (1) The Thinker Sucks!; (2) Drama Horor; (3) Stop!!! Stop!!!; (4) Slow Song or Sad Song?; (5) Pelajaran Menarik; (6) Knocked Down!;
(7) Cinca..Jijay..; (8) Fuga Pleasure; (c) September (3) $¥$ terdapat posting artikel sebanyak tiga buah judul, sebagai berikut; (1) Terhenyak....; (2) Sedikit Menghela Nafas di Tengah Medan Perang; (3) Cinta Harus Memilih Bukan?; (d) July (5) $\ddagger$ terdapat posting artikel sebanyak lima buah judul, sebagai berikut; (1) Luv U My Little sweeties; (2) Letters from My Students; (3) Letters from My Students; (4) Letters from My Students 1; (5) The Two Selves Soliloquy.

Posting paling tinggi tiga bulan terakhir dilakukan selama bulan Oktober, peringkat selanjutnya adalah bulan Juli, kemudian bulan September. Berdasarkan hasil wawancara Najmah menuturkan bahwa tidak setiap saat dirinya memiliki kemampuan konstan untuk membangun mood menulis. Hal ini berakibat pada substansi seringkali posting sekedar pengalaman muridnya di institusi tempat Najmah mengajar atau berupa puisi yang merupakan ekspresi spontan saja. Berdasarkan pengamatan, Blog ini tidak memiliki jadwal teratur dalam jumlah dan waktu posting. Karenanya tidak terlalu berpengaruh pada komunitas yang memiliki link dengan Blog ini, asumsinya adalah Blog ini tidak memiliki keterikatan dalam sebuah aktifitas distribusi informasi yang jelas terkait jumlah posting yang terjadwal dengan topik-topik aktual.

\section{Level Treatment Recommendation}

Berdasarkan hasil pengamatan Blog dan wawancara pemilik Blog terdapat beberapa hal berikut, Najmah menggunakan tag line: Speaking with Life... Home is where one starts fromT.S. Eliot- ingin menjembatani atas keinginan mengekspresikan pemikiran melalui jalur yang lebih mudah diterima publik tanpa melalui proses framing dan perubahan kontruksi sehingga makna yang diwacanakan secara implisit, lugas tidak direduksi oleh sebuah proses gatekeeping media. Menurutnya ini upaya untuk meraih kebebasan berargumen bagi siapa pun melalui medium yang personal namun memiliki jangkauan global. Tag line dari Blog ini mengukuhkan semangat freedom are from dalam bentuk tulisan yang beragam. Hal ini diciptakan Najmah untuk menegaskan bahwa setiap pribadi dapat menjadi seorang jurnalis bagi dirinya sendiri, juga mem- 
bebaskan publik untuk menilai dan menkmati karya-karya Blogger.

Aktifitas Blogger sebagai media refleksi personal.

Level Define Problem; Melihat posting Blog Najmah maka publik akan mudah menebak bahwa Najmah tertarik dengan persoalan sisi kemanusiaan, menggunakan bahasa yang sarat metafora. Pemilihan diksi dan konstruksi kalimat ini demi kalimat menciptakan human sense yang kuat. Dalam format jurnalistik kita tidak hanya mengenal tulisan feature yang masuk kategori soft news saja namun paling utama karena menang dalam layout posisi hard news (straight news) menempati posisi penting. Tentunya Blog Najmah belum merefleksikan kedua mainstrem berita tersebut.

Level Diagnose Causes; Dari total posting selama tiga bulan maka dapat di kategorikan bahwa tulisan Najmah tidak mewakili persoalan skala prioritas berdasar news value berita. Hal ini merujuk pada format penempatan berita berdasar magnitude dan agenda publik yang memang membutuhkan isu penting dalam hitungan waktu. Substansi penulisan secara global berupa catatan harian dalam bentuk opini dengan menggunakan gaya bahasa sastra.

Level Make Moral Judgement; Nilai moral yang hendak ditawarkan dari akumulasi posting selama tiga bulan adalah upaya membangun eksistensi dan kepercayaan diri. Hasil posting dari artikel bulan Oktober dan bulan Juli menunjukkan liberalisme pengungkapan pemikiran dan letupan perasaan yang tidak mudah bagi setiap orang mengatasi ketidakpastian dalam komunikasi tatap muka ternyata mampu digambarkan secara ekspresif oleh Najmah. Aktifitas ini menunjukkan peran bahwa komunitas merupakan agen yang mampu mengkonstruksi persoalan diri untuk memberikan solusi dan motivasi bagi pihak lain untuk mengatasi kendala psikologis dengan menulis. Najmah memberikan justifikasi bahwa medium seperti Blog memiliki kesempatan melahirkan sisi kreatifitas yang tidak terpenjara karena membebaskan aliran pemikiran tanpa dipengaruhi oleh ideologi sistem besar seperti hanya dalam industri media massa.

Level Treatment; Dalam menempatkan media personal Najmah membuat kategori tulisan berdasar antara posting yang berisi tulisan ilmiah dan termasuk dalam kategori pribadi. Najmah melakukan pemisahan web, hal ini dilakukan dengan maksud untuk lebih memfokuskan pada topik yang akan diposting berikutnya. Untuk mengatasi kebutuhan akan kualitas artikel yang bersifat ilmiah seperti resensi buku, tulisan jurnal, opini faktual, najmah menyediakan link ke Blog Multiply yang disediakan di situsnya. Blogger lain atau pembaca dapat dengan mudah meng'klik' situs multiply dan mengunduh kebutuhan informasi sesuai dengan topik yang diinginkan.

Subhanafifi.blogspot.com dengan pemilik Blog Subhan Afifi (Blogger); subhanafifi.blogspot. com diterbitkan pada tanggal 22 Maret 2008 memiliki judul (title) Subhanafifi.blogspot.com. Dari tiga bulan pengamatan beberapa posting maka diperoleh karakter posting sebagai berikut; 2008 (13) menunjukkan bahwa terdapat 13 kali posting ke artikel dalam kurun waktu satu tahun terakhir. Berikut adalah pengamatan empat bulan terakhir posting artikel yang dilakukan Blogger; (a) Mei (3) $\ddagger$ terdapat tiga buah judul artikel yang diposting pada bulan ini yakni; (1) Ketika Penulis Blog Ditangkap; (2) Kun Fa Yakun di Kuala Lumpur; (3) Mediamorfosis Gaya Malaysia; (b) Juni (3) $¥$ terdapat posting artikel sebanyak tiga buah judul, sebagai berikut; (1) Perkembangan Teknologi Komunikasi; (2) Komunikasi Kontemporer; (3) Berlibur Ke Perpustakaan; (c) Juli (1) $\ddagger$ terdapat posting artikel sebanyak sebuah judul, sebagai berikut; Bermula dari Niat; (d) September (2) ‡ sekama bulan september Blogger memposting dua artikel, sebagai berikut; (1) Ramadhan dan Perubahan; (2) Pengumuman; (3) Melalui pengamatan dimulai sejak bulan Mei, Juni, Juli hingga Oktober maka, Blog ini memiliki karakter media pemikiran dan media pembelajaran Blogger. Terlihat pada beberapa posting artikel bahasa yang digunakan bersifat formal, kategori yang ditampilkan berupa informasi, nuansa religius, pendidikan, parenting, perjalanan. Subhan berpendapat Blog ini digunakannya untuk menuangkan ide, pemikiran, pengalaman,renungan, uneguneg atau bahkan kesedihannya. Ditandai dengan kolom "komentar" yang memungkinkan relasi komunitas Blogger terlibat langsung dengan memberikan komentar seputar artikel yang diposting, dapat dilihat pada artikel berikut; Ketika Penulis 
Blog Ditangkap; Rabu, 2008 Mei 07; Tadi malam saya berdiskusi, tepatnya mewawancarai, pensyarah (dosen) jurusan Penyiaran dan Film, Universiti Malaya, Abu Hassan Hasbullah, tentang prasangka budaya Indonesia-Malaysia di Media Massa.

Dua negara yang katanya serumpun itu sering menghadapi masalah dalam hubungan. Citra Indonesia, kalau kita membaca media Malaysia, memang tidak begitu sedap. Judul-judul berita seperti ini dapat ditemui; "Curiga dengan Koloni Indon”, “Indon Asingkan Diri, Enggan Campur Gaul Masyarakat Tempatan Meskipun ada Antara Mereka Miliki PR”, "Geng Indon Pecah Rumah Hujung Minggu Mengganas", "Malaysia tidak Kemaruk Indon", "Amah Indon Lega Tinggalkan LCCT", "Indons and Filipinos Top In Crime”, "Indons Robbed, Woman Rapped”, "Warga Indon dituduh Samun Suri Rumah”, "Indon Cemar $K L$ ”, dan masih banyak lagi. KBRI KL telah melayangkan surat protes tentang penyebutan kata "Indon" yang bernada merendahkan itu, tapi tetap saja media masih menggunakannya, walau sudah agak berkurang. Di tataran masyarakat Malaysia, kata "Indon" sudah sangat popular untuk menyebut warga Indonesia dengan konotasi bermasalah.

Media Indonesia pun dikritik karena dianggap tidak berimbang dan sering menjelekjelekkan Malaysia. "Media Seberang Tak Adil, Stesen TV Lapor Berita Negatif Mengenai Malaysia Setiap Hari”, begitu judul berita Harian Metro 13 September 2007. Begitulah!

Menurut Abu yang juga jadi penyelia thesis $\mathrm{PhD}$ saya, citra negatif tentang orang Indonesia di media massa Malaysia atau sebaliknya, sudah sepatutnya dihentikan. Karena era kesejagad-an tak lagi menyediakan tempat bagi pertentangan karena hal yang "remeh-temeh". Persoalan pencitraan negatif, khususnya tentang orang Indonesia di Malaysia, menurut Abu, tak lepas dari aspek ekonomi politik media. "Mediamedia mainstream Malaysia dikendalikan partai berkuasa, UMNO. Citra seperti itu tak ditemui di media-media alternatif," katanya. Abu menjelaskan panjang lebar bahwa ke depan, beritaberita yang mencitrakan negatif Negara lain tak akan laku di Malaysia, karena masyarakat semakin kritis dan terbuka.

Abu Hassan merupakan salah satu dosen UM yang sering bersuara kritis. Beliau sering diundang berbagai stasiun televisi di Malaysia untuk menjadi narasumber dalam talkshowtalkshow politik terkini. Komentar-komentar tajamnya terhadap penguasa, tak urung membuat ada salah seorang wartawan media Malaysia bertanya : “Apa tidak takut ditangkap?". Abu hanya tersenyum dan berkata; "Pak Lah berbeda dengan Mahathir, saya menyuarakan pendapat untuk perbaikan masyarakat," katanya di belakang setir, ketika mengantarkan saya pulang ke kolej 11, pukul 11 malam.

Tadi pagi, saya terkejut membaca Berita Harian. Dua penulis Blog, Raja Petra Raja Kamaruddin dan Syed Akbar Ali, ditangkap polisi karena menulis artikel yang dianggap menghasut di Blog Malaysia-Today. Ini adalah kali pertama penulis Blog didakwa berdasarkan Seksyen empat (1) (c) Akta Hasutan 1948 dengan hukuman maksimum denda RM5,000 atau penjara tiga tahun.

Raja Petra ditangkap karena menulis artikel berjudul Let's Send The Altantuya Murderers To Hell dalam web malaysia-today.net (25/ 4/08). Sementara Syed Akbar, dikenakan tuduhan menghasut karena menulis komentar berjudul It Is Easy To Impress The Malays. Itu adalah komentar terhadap artikel Raja Petra berjudul $M a$ laysia's Organised Crime Syndicate; All Roads Lead To Putrajaya.

Nah....

Label: KOMUNIKASI DAN MEDIA

\section{Define Problems}

Sebenarnya ada dua hal yang ingin disampaikan oleh Subhan dari artikel di atas. Pertama, fenomena Bangsa Indonesia di negeri Jiran sangat memprihatinkan. Image Bangsa Indonesia di mata Bangsa Malaysia sangat buruk dan rendah. Hal ini tercermin dalam tulisan-tulisan yang dimuat pada media massa Malaysia. Walau sudah diperingatkan oleh KBRI KL namun tetap saja bermunculan tulisan-tulisan bernada merendahkan bangsa Indonesia. Judul-judul di berbagai media massa yang memojokkan bangsa Indone- 
sia terutama dengan sebutan "Indon". Citra Indonesia di mata Malaysia rendah. Subtansi kedua dari artikel Subhan adalah fenomena terbelenggunya kebebasan hak berpendapat menuangkan ide secara bebas di media yang sifatnya independen sekalipun di negara Jiran. Area publik (public sphere) sebenarnya terbelenggu di negara Jiran contohnya adalah berita ditangkapnya penulis Blog karena menulis artikel miring seputar Pemerintah Malaysia. Sebagai mahasiswa Indonesia yang menuntut ilmu di negeri Jiran ini, Subhan sangat "risih" dengan tulisan-tulisan di berbagai media massa yang memberitakan secara miring tentang bangsa Indonesia yang sebenarnya Negara Malaysia sendiri banyak kelemahan pada Sistem Pemerintahannya.

\section{Diagnose Cause}

Malaysia sebagai negara Jiran melecehkan Indonesia dengan berbagai berita yang dimuat di media massa. Sebutan "Indon" bagi bangsa Indonesia merupakan salah satu bentuk pelecehan di samping masih banyak lagi yang lainnya. Kalau hal ini tidak diantisipasi dengan mengkonter baik dari pemerintah Indonesia maupun masyarakat Indonesia sendiri maka, Malaysia akan terus menjadi-jadi menginjak-injak martabat Bangsa Indonesia. Pemerintah Malaysia dalam menjalankan roda pemerintahan sebetulnya sangat tersentralisasi. Hal ini tampak pada kasus ditangkapnya penulis Blog. Raja Petra mengkritisi pemerintahan Malaysia melalui artikelnya yang berjudul Let's Send The Altantuya Murderers To Hell dalam web malaysia-today.net (25/4/08). Sementara Syed Akbar, dikenakan tuduhan menghasut karena menulis komentar berjudul It Is Easy To Impress The Malays. Itu adalah komentar terhadap artikel Raja Petra berjudul Malaysia's Organised Crime Syndicate; All Roads Lead To Putrajaya. Padahal seperti yang kita ketahui bahwa Blog merupakan area publik (public sphere) melalui dunia maya dimana setiap Blogger bebas menulis apa saja, kemudian siapapun boleh mengkomentarinya. Sesama komunitas Blog dapat bertukar ide, gagasan, informasi, curahan hati, dan sebagainya tanpa campur tangan pemerintah. Pemerintah Malaysia tidak bisa menerima kritik dari rakyatnya sekalipun lewat dunia maya. Ini sungguh fenomena yang ironi, di era kebebasan di ruang publik yang bersifat independent, pemerintah justru intervensi jauh ke dalamnya.

Subhan menyampaikan dengan bahasa formil mengandung makna jurnalistik. Ada fakta yang dimuat di media massa kemudian dikomentari dan dibarengi dengan pengalaman pribadi Subhan selama di Malaysia. Tulisan Subhan ini sebetulnya merupakan konter pribadi terhadap penghinaan-penghinaan yang dilakukan masyarakat Malaysia terhadap Bangsa Indonesia. Sebetulnya pemerintah Malaysia sendiri belum dapat menerima perbedaan pendapat dan kritik dari rakyatnya sendiri, sementara Pemerintah Malaysia membiarkan seakan merestui rakyatnya melecehkan Negara tetangga.

Penyebab semuanya ini sebenarnya menurut Penyelia Subhan, Abu Persoalan pencitraan negatif, khususnya tentang orang Indonesia di Malaysia, tak lepas dari aspek ekonomi politik media. "Media-media mainstream Malaysia dikendalikan partai berkuasa, UMNO. Citra seperti itu tak ditemui di media-media alternatif," katanya.

\section{Make Moral Judgement}

Apakah semua Bangsa Malaysia menganggap Indonesia rendah atau sependapat dengan berita yang dihembuskan oleh media? Ternyata tidak. Dari segelintir orang seperti Abu Hasan, Peyelia Subhan berpendapat lain, beliau orang yang sangat fair dan independent dalam mengemukakan pendapat tentang politik. Beliau mencoba mengambil jalan tengah bahwa hendaknya kedua belah pihak (Indonesai dan Malaysia) segera menghentikan ini semua. Karena era ke-sejagad-an tak lagi menyediakan tempat bagi pertentangan karena hal yang "remeh-temeh". Beliau juga menambahkan bahwa ke depan, berita-berita yang mencitrakan negatif Negara lain tak akan laku di Malaysia, karena masyarakat semakin kritis dan terbuka.

\section{Treatment Recomendation}

Subhan memunculkan judul artikel "Ditangkapnya Penulis Blog" disebabkan kekhawatirannya akan arti kebebasan menuangkan 
pendapat di dunia maya. Kasus tersebut belum pernah terjadi di Indonesia. Subhan mencoba menginformasikan sekaligus memberikan warning bagi komunitas Blog untuk lebih berhati-hati lagi dalam menuangkan pikiran, pendapat. Contoh kasus di Malaysia penulis Blog ditangkap karena artikel yang dipostingnya dianggap menghasut. Ada tiga point penting daritulisan Subhan. Pertama peringatan bagi sesama penulis Blog agar lebih berhati-hati dalam menyampaikan pendapat dan gagasan. Kedua sebagai informasi bahwa di ruang publik sekalipun di negara Malaysia rakyatnya tidak bisa bergerak secara bebas. Ketiga secara implicit Subhan mencoba mengkritisi Pemerintah Malaysia dengan menampilkan Abu Ha-san sebagai Penyelianya yang notabene seorang berkebangsaan Malaysia, namun sangat kritis terhadap politik Pemerintahan Malaysia.

Kun Fa Yakun di Kuala Lumpur; Minggu, 2008 Mei 04; May Day lalu, saya beruntung berkesempatan ikut pengajiannya Ustadz Yusuf Mansur di KBRI Kuala Lumpur. Seperti biasanya, seperti yang kita lihat di layar televisi, Ustadz muda itu membawakan tema kekuatan sedekah. Yang membuat saya terkesan, adalah matematika sedekah yang ditawarkannya untuk menjadi solusi apapun masalah yang kita hadapi. Mulai dari kekurangan uang, terlilit hutang, sakit, ingin melanjutkan sekolah, tidak dikaruniai anak, hingga belum kunjung ketemu jodoh. Apapun!

Ustadz Yusuf Mansur tidak sekedar sedang berteori, tapi bercerita dari pengalaman nyata. Ia sendiri pernah terlilit hutang Rp. 1,4 Milyar, dan mampu diselesaikan dalam waktu tiga tahun. Demikian juga dengan testimoni para pendengar pengajiannya di berbagai kota. Inti dari matematika sedekah itu adalah : tidak akan berkurang harta yang kita sedekahkan, bahkan bertambah. Jika kita punya uang Rp.110.000, kita sedekahkan Rp.10.000 maka sisa uang itu bukan menjadi Rp.100.000, tetapi menjadi Rp 200.000. Ini karena Rp.10.000 yang disedekahkan itu akan dikembalikan Allah menjadi 10 kali lipatnya (=Rp.100.000). Maka dengan rumus yang sama, jika uang Rp110.000 itu disedekahkan Rp.100.000, bukan bersisa Rp.10.000, tetapi menjadi Rp.1.010.000. Lagi-lagi karena, yang Rp100.000 itu dikalikan 10. Seorang mahasiswa yang diminta maju ke depan saat pengajian itu, dan hanya membawa uang RM 22, memilih untuk memberikan sedekah RM20, bukan RM2, karena menurut hitung-hitungan matematika sedekah, uangnya akan berlipat menjadi RM202.

Jadi, kata Ustadz, "kalau mau sedekah dan ingin masalah teratasi jangan tunggu uang sisa, karena pasti uang kita nggak bakalan ada sisanya." Kalau ingin dapat rezeki besar bersedekahlah. Ingin motor atau mobil baru, bukan dengan mengajukan kredit, tapi bersedekahlah 10 persennya dari total harganya, maka dengan izin Allah, rezeki itu akan datang. Punya utang tak lunas-lunas, sedekahkan 10 persen dari total utang. Buat yang sedang nyari jodoh, Ustadz menyarankan untuk "menghitung" kira-kira suami yang diidam-idamkan bergaji berapa sebulan, kalikan 12 (setahun), tambahkan dengan biaya pernikahan dan lainlain. Dan bersedekahlah 10 persen dari totalnya, InsyaAllah suami dambaan segera datang. Mau naik haji cepat, infakkan 10 persen dari Ongkos Naik Haji. Ringkasnya, masalah apapun Insya Allah akan teratasi dengan rumus itu. Tentu saja semuanya harus dengan keyakinan.

Subhanallah, saya kagum dengan cara Ustadz itu menginspirasi dan menggerakkan banyak orang. Para jamaahpun ramai-ramai meletakkan uang sedekah di sorban yang digelar Ustadz, dan menulis komitmen jumlah rupiah yang akan disumbangkan untuk program PROGRAM PEMBIBITAN PENGHAFAL ALQUR'AN DAARUL QUR'AN, di Pondok pesantren Wisata Hati yang dipimpinnya.

Saya pun pulang dengan semangat baru. Hanya saja, saya masih bertanya-tanya, apakah sedekah yang kita berikan hanya didorong oleh hitung-hitungan matematis, "berapa" yang akan kembali lagi ke kita? Bagaimana kita menjaga keikhlasan? Di akhir pengajian, memang Ustadz menyampaikan bahwa apa yang dijelaskannya masih "Gigi Satu"; bersedekah karena ingin menyelesaikan masalah. Di tahap berikutnya, ada sedekah yang didorong karena syukur kepada Allah, karena cinta kepada Allah. Mungkin itu jawabannya. Alhamdulillah saya mendapat pencerahan hari itu.

DIPOSKAN OLEH SUBHAN AFIFI DI 01:00 9 komentar link ke posting ini. 


\section{Define Problem}

Banyak masyarakat yang belum menyadari bahwa dalam ajaran Agama Islam terdapat banyak tuntunan, di samping dapat membawa kita pada kebahagian dan kesejahtertaan hakiki di akherat kelak juga kebahagian hidup di dunia. Salah satu ajaran itu adalah dengan bersadaqoh. Rasulallah SAW selalu menganjurkan umatnya untuk bersadakah, karena banyak keuntungan yang akan didapat dari bersadakah. Salah soerang pengikut Rasul yang bersemangat mendakwahkan pentingnya sadakah adalah Ustadz Yusuf Mansur. Ustadz muda ini mengusung satu tema Dakwahnya adalah Matematika sadakah. Subhan dalam salah satu lawatannya di Malaysia mndapat kesempatan untuk mengikuti ceramh Ustadz Yusuf Mansur ini. Subhan sangat terkesan dengan materi yang disajikan. Ternyata dengan sadakah banyak masalah dapat diatasi. Misalnya ingin menikah, maka bersedakahlah 10 persen dari total biaya nikah dan seterusnya. Namun sayangnya muncul pertanyaan besar dalam diri Subhan, apakah sedekah yang kita lakukan hanya mengharapkan imbalan secara langsung yang sifatnya duniawi? Bagaimana dengan konsep keikhlasan sehingga membawa kita pada kebahagiaan hakiki? Ternyata apa yang disampaikan Ustadz tersebut barulah gigi satu ungkapan bagi pemula.

\section{Diagnose Cause}

Subhan merasa selama ini dia belum menyadari kalau sadakah yang dilakukannya ternyata mengandung unsur matematis. Sadakah semata hanya mengharap Ridho Allah SWT. Sebatas Itu yang dipahami Subhan selama ini. Setelah mengikuti pengajian Ustadz Yusuf mansur, barulah dia menyadari ternyata sadakah bisa dimatematikakan. Ustadz Yusuf Mansur tidak sekedar sedang berteori, tapi bercerita dari pengalaman nyata. Ia sendiri pernah terlilit hutang Rp. 1,4 Milyar, dan mampu diselesaikan dalam waktu tiga tahun. Inti dari matematika sedekah itu adalah : tidak akan berkurang harta yang kita sedekahkan, bahkan bertambah. Jika kita punya uang Rp.110.000, kita sedekahkan Rp.10.000 maka sisa uang itu bukan menjadi Rp.100.000, tetapi menjadi Rp 200.000. Ini karena Rp.10.000 yang disedekahkan itu akan dikembalikan Allah menjadi 10 kali lipatnya (=Rp.100.000). Maka dengan rumus yang sama, jika uang Rp110.000 itu disedekahkan Rp.100.000, bukan bersisa Rp.10.000, tetapi menjadi Rp.1.010.000. Lagilagi karena, yang Rp100.000 itu dikalikan 10 .

Diakhir cerita Ustadz mampu menggerakkan jama'ah untuk bersadakah dengan meletakkan uang sedekah di sorban yang digelar Ustadz, dan menulis komitmen jumlah rupiah yang akan disumbangkan untuk program PROGRAM PEMBIBITAN PENGHAFAL ALQUR'ANDAARUL QUR'AN, di Pondok pesantren Wisata Hati yang dipimpinnya.

Ada keuntungan ganda yang diperoleh baik dari Ustadz maupun bagi jama' ah. Bagi Ustadz selain mengajak orang lain untuk beramal sholeh dengan sadakah, juga dapat menghidupkan pesantren yang dibinanya yakni Pondok pesantren Wisata Hati dengan program PEMBIBITAN PENGHAFAL ALQUR'AN-DAARUL QUR' AN. Bagi jama' ah mendapat pahala amal sholeh bersadakah dan mengharap pahala dari Allah SWT. berupa komitmen yang mereka buat.

\section{Make Moral Judgement}

Mencermati pengalaman pengajian yang diikuti oleh Blogger (Subhan) di atas memang menarik untuk dijadikan panutan. Subhan mencoba menggugah para pembaca artikel yang dipostingnya ini agar mau mendekatkan diri pada Sang Maha Pencipta melalui sadaqah. Di samping untuk mengingatkan dirinya pribadi. Pengajian Ustadz Yusuf Mansur ini menjadi perenungan bagi Subhan akan arti sadaqoh. Subhan merasa mendapat "pencerahan" dari segi spiritual dan dia berusaha membagi pencerahan ini kepada para pembaca Blog-nya ini. Beragam tanggapan yang diberikan oleh para pembaca, bisa dilihat pada kolom komentar. Sebagian besar tanggapan sependapat dengan tulisan Subhan ini bahkan ada yang berterima kasih telah diingatkan, ada pula yang penasaran tidak pernah bisa mengikuti pengajian ustadz Yusuf Mansur. Karakter para pembaca pada artikel ini tampaknya hampir sama dengan Subhan yakni Muslim yang sama-sama mencari Pencerahan dan dari kalangan intelektual. 


\section{Treatment Recomendation}

Anjuran Ustadz Yusuf mansur mendapat respon yang sangat positif dari jama'ah yang mendengarkan. Sebagai pendengar Subhan terpukau dengan kemampuan ustadz tersebut menggerakan hati jama'ahnya. Ini tampak pada kutipan berikut;

Subhanallah, saya kagum dengan cara Ustadz itu menginspirasi dan menggerakkan banyak orang. Para jamaahpun ramai-ramai meletakkan uang sedekah di sorban yang digelar Ustadz, dan menulis komitmen jumlah rupiah yang akan disumbangkan untuk program PROGRAM PEMBIBITAN PENGHAFAL ALQUR'AN DAARUL QUR'AN, di Pondok pesantren Wisata Hati yang dipimpinnya.

Diantara tulisan Subhan yang diposting judul tulisan kun faya kun ini yang banyak mendapat respon dari sesama Blogger. Mereka tergerak untuk menomentari dan tersadar akan pentingnya sadakah. Terlepas dari niat yang baru sampai gigi satu yang jelas secara umum mereka memberi komentar Subhan memberi pencerahan bagi mereka dan menganggap Subhan juga Ustadz yang sedang berceramah lewat artikel Blog.

Bermula dari Niat; Selasa, 2008 Juli 29; Ketika menyusuri jalan panjang Jeddah-Madinah, Januari lalu, saya membayangkan betapa beratnya perjalanan hijrah dari Mekkah ke Madinah yang ditempuh Rasululloh SAW dan para sahabatnya. Padang pasir yang super panas dan gersang terlihat sejauh mata memandang. Perjalanan dengan bis nyaman ber AC sejuk saja terasa lama dan membosankan, apalagi perjalanan dengan berjalan kaki atau naik onta, seperti mereka, orang-orang terbaik sepanjang masa itu. Selain alam yang ganas, mereka masih dibayang-bayangi para musuh yang beringas dan siap membunuh. Hanya keimanan yang tinggi dan harapan akan kehidupan nikmat sesudah kematian saja yang bisa mengalahkan segala kesulitan.

Tapi tunggu, saya teringat dengan sebuah hadist terkait peristiwa hijrah :

"Sesungguhnya setiap amal perbuatan tergantung niatnya. Dan bagi setiap orang, apa yang ia niatkan. Barangsiapa yang berhijrah karena Allah dan Rasul-Nya, maka hijrahnya itu ke arah (keridhaan) Allah dan Rasul-Nya. Barang siapa yang berhijrah karena dunia (harta atau kemegahan dunia), atau karena seorang wanita yang ingin dikawininya, maka hijrahnya seperti yang ia niatkan."

Subhanallah, perbuatan boleh sama, kesulitan yang dihadapi serupa, tapi hasilnya bisa berbeda 100 persen. Ternyata tak semua yang berhijrah itu benar-benar mengharap ridho Allah. Ada juga yang menempuh segala kesulitan hanya karena ingin jadi lebih kaya. Bahkan ada karena ingin mengawini pujaan hati. Duh.. sesuatu yang manusiawi, tapi sangat fatal akibatnya.

Semua memang bermula dari niat. Niat dalam hati. Hanya kita dan Allah yang tahu, apa niat kita melakukan segalanya selama ini. Untuk apa sih kita bersusah payah bekerja, jungkir balik seharian, mengejar sesuatu habis-habisan, atau buat yang sedang belajar, kuliah mati-matian? Kalau niatnya hanya untuk dunia, (materi, pujian, atau segala sesuatu yang akan kita tinggalkan) semuanya memang akan kita dapatkan. Tapi betapa ruginya. Seharusnya, segalanya kita niatkan untuk ibadah kepadaNya, mencari keridhoanNya. Dunia dan segalanya akan mengikuti, kalau ridho Allah yang jadi tujuan. Sudah selayaknya niat dibenahi, agar semuanya bermakna, hingga di surga nanti.

Diposkan oleh Subhan Afifi di 02:04 0 komentar Link ke posting ini

\section{Label: JALAN KE SURGA}

\section{Define Problems}

Artikel dengan Judul Bermula dari Niat di atas sarat akan dakwah, mengingatkan, mengajak, mengevaluasi diri dan berperilaku selalu bermuara pada niat. Niat itu ada di dalam hati, sehingga hanya diri tersebutlah yang mengetahuinya dan Sang Maha Pencipta Allah SWT tentunya.

Artikel ini sebetulnya sepenggal kisah perjalanan ibadah haji Subhan. Tulisan tersebut lebih pada curahan isi hati Subhan. Karakter pada tulisan ini lebih pada evaluasi diri, introspeksi diri sekaligus mengingatkan dirinya dan orang lain akan pentingnya niat. Gambaran berabad silam Rasul dan para sahabat melakukan perjalan melewati gurun pasir yang sangat panas, gersang, dan garang 
semua dilakukan demi mengharap Ridho Allah SWT. Keadaannya sangat berbeda dengan sekarang, dimana segala sesuatu dimudahkan oleh fasilitas yang serba modern dan nyaman, tetapi tetap saja manusia itu mengeluh tidak merasa puas. Semuanya tergantung pada niat, hijrah seseorang tergantung niatnya.

\section{Diagnose Cause}

Seseorang melakukan segala sesuatu karena didorong oleh niat. Niat ini seperti fatamorgana, artinya sesuatu yang sepertinya tampak sesungguhnya bisa jadi berbeda dengan yang tampak atau bahkan tidak ada. Apa yang tampak oleh orang lain baik bisa jadi sebenarnya dibalik itu terselip niat yang buruk. Atau dalam perjalanan bisa pula niat itu berubah entah jadi baik atau malah sebaliknya. Karena letaknya di dalam hati. Itulah manusia, mereka melakukan segala perbuatan diawali dari niat. Subhan menuangkan ini dengan kalimat sebagai berikut;

Subhanallah, perbuatan boleh sama, kesulitan yang dihadapi serupa, tapi hasilnya bisa berbeda 100 persen. Ternyata tak semua yang berhijrah itu benar-benar mengharap ridho Allah. Ada juga yang menempuh segala kesulitan hanya karena ingin jadi lebih kaya. Bahkan ada karena ingin mengawini pujaan hati. Duh.. sesuatu yang manusiawi, tapi sangat fatal akibatnya.

Hijrah seseorang tergantung dari niatnya. Subhan berusaha merenung bahwa banyak orang melakukan perbuatan yang tampaknya sama tetapi ternyata hasilnya berbeda. Itu semua kuncinya ada pada niat seseorang. Yang sering terjadi di zaman sekarang ini adalah orang mengaku melakukan sesuatu karena mengharap Ridho Allah, tetapi ternyata hasilnya malah sebaliknya. Contohnya menikah, perbuatan menikah adalah sunnah tetapi niat seseorang menikah bisa jadi karena sangat mencintai pujaan hatinya bukan karena kecintaannya pada Allah yang menciptakan pujaan hatinya tersebut.

\section{Make Moral Judgement}

Pesan moral yang ingin disampaikan Subhan adalah betapa penting meluruskan niat ketika kita hendak melakukan suatu amalan atau perbuatan. Niat yang baik akan berbuah hasil yang baik sesuai dengan hadist Rasulullah SAW yang disitir Subhan sebagai berikut;

"Sesungguhnya setiap amal perbuatan tergantung niatnya. Dan bagi setiap orang, apa yang ia niatkan. Barangsiapa yang berhijrah karena Allah dan Rasul-Nya, maka hijrahnya itu ke arah (keridhaan) Allah dan Rasul-Nya. Barang siapa yang berhijrah karena dunia (harta atau kemegahan dunia), atau karena seorang wanita yang ingin dikawininya, maka hijrahnya seperti yang ia niatkan".

\section{Treatment Recomendation}

Teladan yang bisa kita petik adalah ungkapan Subhan pada alinea pertama; "saya membayangkan betapa beratnya perjalanan hijrah dari Mekkah ke Madinah yang ditempuh Rasululloh SAW dan para sahabatnya. Padang pasir yang super panas dan gersang terlihat sejauh mata memandang. Perjalanan dengan bis nyaman ber AC sejuk saja terasa lama dan membosankan, apalagi perjalanan dengan berjalan kaki atau naik onta, seperti mereka, orang-orang terbaik sepanjang masa itu. Selain alam yang ganas, mereka masih dibayang-bayangi para musuh yang beringas dan siap membunuh. Hanya keimanan yang tinggi dan harapan akan kehidupan nikmat sesudah kematian saja yang bisa mengalahkan segala kesulitan".

Tidak gampang memang meniru semangat Rasulullah dan para sahabat. Kalaupun belum bisa melakukan hal yang sama, paling tidak kita bisa meniru niat mulia Rasulullah dan para Sahabat. Perjalanan haji yang dilakukan Subhan sebenarnya sudah sangat jauh lebih nyaman dan mudah dibanding Rasulullah dan para sahabat. Tetapi manusia selalu saja mengeluh merasa perjalanan tersebut membosankan. Untuk membersihkan hati dari keluh kesah dan sebagainya adalah dengan meluruskan niat.

\section{Analisis Jenjang Teks}

Pemahaman Blogger untuk memilih medium Blog sebagai media ekspresi

Tulisan-tulisan yang diposting oleh Subhan, sarat akan dakwah dan pengalaman. Subhan membuat Blog ini diawali oleh hobi menulis. Ada 
tujuh kategori dalam Blog Subhan, diantaranya kategori jalan ke surga, ini merupakan refleksi Subhan terhadap masalah-masalah ke Islaman. Segmennya jelas yakni muslim yang ingin berbagi tentang keislaman atau ajaran Islam. Kemudian ada kategori komunikasidan media. Kategori ini berisi tulisan-tulisan yang berkaitan dengan komunikasi dan media sesuai dengan bidang Subhan sehingga segmen pembaca adalah mereka yang memiliki minat terhadap komunikasi dan media media.

\section{Aktifitas Blogger sebagai Media Refleksi Personal}

Bagi Subhan Blog merupakan wadah untuk menyalurkan hobi menulis. Terkait dengan pe-ngalamannya menulis di media cetak. Meskipun tidak semua tulisannya dimuat di media cetak. Awalnya subhan membuat Blog untuk memasukan tulisan baik yang telah dimuat atau yang tidak dimuat oleh media cetak. bila dilihat lebih seksama, maka tulisan Subhan terlihat sangat panjang untuk artikel Blog. Karena ide awalnya tulisan tersebut ditujukan untuk media cetak. konsep tulisan Subhan tidak seperti catatan harian yang setiap saat ditulis dengan menggunakan bahasa yang mendayu-dayu.namun catatan harian ini merupakan hal yang bermanfaat bagi Subhan sendiri dan bagi pembacanya, tentu saja didalamnya memuat idealisme yang bertujuan untuk berdakwah. Menurut Subhan, diharapkan orang lain menjadi tercerahkan dan mendapat petunjuk.

Dari beberapa hasil pengamatan dan hasil penelusuran yang penulis lakukan, terdapat beberapa kecenderungan Webblog yang seterusnya dapat kita pahami sebagai berikut; (a) Keberadaan Webblog mampu menghasilkan iklim kebebasan berinformasi yang mendorong lahirnya desentralisasi pesan dalam setiap orang; (b) Komunikator yang sifatnya perorangan ini mendorong konsep Webblog sebagai media yang lebih personal yang memuat unsur independen karena melepaskan diri dari kontrol dan proses gatekeeping media yang berbelit-belit.

Serangkaian proses pengamatan terhadap objek penelitian, telah menghasilkan beberapa pemahaman yang dapat kita kategorikan sebagai berikut;

\section{Refleksi Jurnalisme Massa dalam Konsep Jurnalisme Weblog}

Aktifitas yang terlibat dalam proses jurnalisme melibatkan keterampilan dalam mencari, mengolah, dan menyusun serta menyuguhkan realitas terkait peristiwa yang terjadi sehari-hari. Jurnalisme merupakan teknik menyampaikan pesan dengan jangkauan luas dan bersifat massif. Adapun jurnalisme Weblog mulai kita kenal seiring dengan kemajuan dunia maya dalam menghadirkan berbagai fitur-fitur operasi yang sangat beragam (My Space, Friendster, Face Book, dan sebagainya). Kecepatan internet bagi sekelompok masyarakat kita dijadikan sarana dalam up load berbagai peristiwa dengan leluasa. Kegiatan ini menjadi sebuah mode baru dalam jurnalisme maya yang memanfaatkan situs Webblog sebagai medium untuk menyusun dan menampilkan informasi untuk publik.

Tentunya untuk merumuskan sebuah aktifitas Webblog dalam kategori Jurnalisme diperlukan beberapa elemen khusus yang menandai bahwa konsep Webblog memiliki tipe dan inheren dari aktifitas jurnalisme pada umumnya. Diawali ketika teknologi web ditemukan, maka web dilihat sebagai medium yang mempermudah seseorang untuk dapat menerbitkan naskah secara online. Seseorang tidak memerlukan sebuah birokrasi yang berbelit-belit untuk mampu menyebarkan sebuah naskah. Sehingga ketergantungan terhadap sebuah perusahaan penerbitan bisa dihilangkan. Situasi ini memberikan peluang bagi publik untuk mempublikasikan hasil tulisan serta potensi karya tulisnya pada khalayak. Berbeda halnya dengan jurnalisme cetak yang media coverage nya sangat terbatas, sementara web mampu menjangkau dalam hitungan detik dan berpotensi dibaca oleh orang di seluruh dunia.

Terdapat bagian-bagian dari aktifitas jurnalisme Webblog yang banyak menduplikasi aktifitas Jurnalisme konvensional (cetak) dengan memanfaatkan teknologi internet yang bersifat soliter, independen, bebas, dan fleksibel. Keberadaan Webblog semakin menjadi media alternatif ketika mampu mengalihkan keteraturan, strukturasi dalam institusi media massa junalistik cetak. Beberapa hal yang menjadi pencetus utama, Webblog diadaptasi sebagai medium sebuah aktifitas 
jurnalistik; pertama, Ketrampilan banyak orang dalam menerbitkan naskah terakomodasi secara fleksibel dengan Blog. Blog yang kemudian lebih populer dengan istilah Webblog umumnya memuat naskah-naskah sederhana yang bersifat kronologis berdasarkan urutan waktu, seperti layaknya jurnal atau catatan harian. Kedua, Webblog merupakan media yang telah diplikasikan secara personal maupun institusional. Karena memuat sejumlah unsur fleksibilitas, maka operasionalisasinya bersifat personal. Sipapun mampu untuk mengelola Webblog-nya. Hanya diperlukan sejumlah persyaratan teknis atau kemampuan menulis untuk mampu mempublikasikan informasinya. Ketiga, dari dua contoh Webblog tersebut, maka dapat kita ketahui sebuah tipologi Blog yang dibuat oleh Blogger tidak berdasar pada sebuah kebijakan redaksional, namun cenderung personal yang tidak melibatkan intervensi atau kontrol eksternal. Kontrol ekstrnal ini dianalogikan sebagai pemimpin redaksi atau serangkaian proses gatekeeper media. Hal ini menunjukkan Webblog memiliki independensi dan otoritas sepenuhnya dalam pengaturan informasi apa yang hendak dipublikasikan, topik apa yang hendak di-up load, bagi siapa informasi tersebut bermanfaat, mengukur ekspektasi pembaca melalui komentar dari Blog dan sebagainya. Keempat, sebagaibentuk media yang memiliki karakter personal, Blogger tidak dipandu oleh sebuh etika jurnalisme dalam publikasi informasi. Lalu lintas informasi antara pembaca dan pencipta $B \log$ tidak memiliki etika standar. Sehingga kita tidak akan menemukan standarisasi headline, dengan formula $5 \mathrm{~W} 1 \mathrm{H}$ atau sebuah agenda setting yang sengaja mempriming isu tertentu yang merupakan pengejawantahan ideologi pemilik media. Pengakses Weblog digolongkan sebagai khalayak yang aktif, sehingga memiliki gratifikasi atas apa yang mereka akses. Terlebih bagi sekelompok massa yang aktif secara online. Publik Weblog adalah mereka yang memiliki kebutuhan atas informasi di dunia maya, jadi pembaca Blog adalah terbatas pada pengguna internet saja. Inilah kontroversi antara masifikasi Webblog dalam kontruksi pesan dan kemasan Webblog sendiri. Di satu pihak Webblog dapat diproduksi secara simultan dalam jumlah banyak, namun media coverage memiliki spesifikasi terbatas ka- rena hanya melayani mereka yang tergolong dalam "melek" internet. Kelima, Jangka terbit atau penyajian informasi (posting) web bersifat insidental, tidak rutin dan tidak bisa diprediksikan. Karena setiap Blogger memiliki asumsi dan kemauan yang berbeda dengan kemauan pembacanya. Hal ini berbeda dengan junalisme konvensional yang sangat teratur dalam penerbitan, karena memiliki komunikator yang melembaga. Keenam, Berbeda dengan jurnalisme cetak yang sangat menekankan pada isi sebagai positioning medianya, Webblog tidak selalu membuat prioritas pemberitaan. Berita dapat berupa hal-hal yang sedang menjadi trend, isu utama atau bahkan remeh temeh yang tidak penting dan menjadi kebutuhan banyak orang. Artinya substansi informasi Blog tidak inheren dengan konsep social surveilance seperti halnya konsep jamak fungsi media massa. Ketujuh, Berbagai alasan diatas, menyebabkan formalitas dalam informasi Blog menjadi tidak diutamakan. Dalam hal ini bahasa dikomunikasikan dengan sekehendak Blogger-nya, sehingga bahasa yang dipakai lebih banyak menggunakan bahasa lisan. Ada juga Blog yang menggunakan bahasa formal, umumnya merupakan Blog komunitas tertentu yang mewakili identitas suatu kelompok.

Berbagai alasan kemudahan tersebut, menjadikan Webblog sebagai media baru yang terus bermetamorfosis untuk menghadirkan perspektif baru mengenai jurnalisme media massa. Sifat independensinya, kesetaraan aksesnya, kebebasan ide dan isinya, merealisasikan konsep jurnalisme akar rumput (grassroot journalism) yang mampu menjembatani sebuah desentarlisasi informasi di era teknologi baru.

\section{Simpulan}

Kehadiran teknologi berbasis internet mendatangkan berbagai temuan baru, terutama terkait medium yang mampu mewakili keinginan individu-individu membangun sistem informasi secara komunal dan personal. Kajian seputar perkembangan teknologi informasi dalam pendekatan media massa banyak dijumpai dalam telaah konvergensi media. Di beberapa perguruan tinggi internasional tingkat sarjana dan pasca sarjana, bahkan dapat kita jumpai mata kuliah 
khusus terkait studi konvergensi media. Hal ini menunjukkan makin terbuka wilayah diskusi dalam konvergensi media yang melibatkan peran media massa.

Merujuk dari data pengguna internet yang mengalami peningkatan daritahun ke tahun ternyata berbagai inovasi terus berkembang sejalan dengan banyaknya pengguna internet yang menginginkan terjadinya bentuk-bentuk media yang lebih personal untuk menjangkau pihak lain dalam waktu singkat, mudah, murah, dan tanpa batasan aturan berinformasi. Salah satu medium yang sangat populer saat ini adalah Blog. Blog merupakan kependekan dari Webblog. Istilah yang dipopulerkan oleh Jorn Barger pada bulan Desember 1997. Barger menggunakan istilah Webblog untuk menyebut kelompok website pribadi yang selalu mengupdate secara kontinyu dan berisi link-link ke website lain yang dianggap menarik disertai dengan komentar-komentar mereka. Kebaruan tema dalam studi konvergensi media ini menjadi pertimbangan bagi peneliti untuk mengajukan riset terkait sejauh mana kehadiran Webblog dalam perspektif komunikasi massa saat ini. Argumen penelitian ini berangkat dari determinasi atas komunikasi massa yang belum sepenuhnya mengembangkan pendekatan Blog sebagai medium yang mampu menciptakan proses desentralisasi informasi publik. Sementara ditengah peningkatan iklim media literasi, publik semakin mencari bentuk medium yang bersifat personal dan menghilangkan hirarki komunikasi konvesional yang menuntut pengaturan.

Dalam perkembangannya Blog mencari bentuk sesuai dengan kemauan para pembuatnya atau para Blogger. Pada awalnya Blog yang berupa catatan perjalanan seseorang di internet, yaitu link ke website yang dikunjungi dan dianggap menarik terus berkembang tidak sekedar sebuah daftar link saja. Hal ini disebabkan karena Blogger selalu mengembangkan bentuk-bentuk isi posting yang semakin berkualitas dan informatif. Hal ini tercermin dari ekplorasi atas dua buah Blog yang dijadikan responden penelitian Blog ini. Identifikasi terhadap Blog Subhan Afifi dan Najmah dapat merumuskan hal-hal berikut, pertama, Blogger menemukan kembali minatnya menulis semenjak memiliki Blog, kedua terjadi proses transfer ide yang menganut kebaruan tema (novelty).
Lebih jauh dua responden ini secara teratur mulai mengupdate Blog-nya, dan mulai mempertimbangkan opini berikut ide-idenya dengan selektif dan hati-hati. Hal ini menunjukkan bahwa kedua responden menyadari bahwa perspektifnya merupakan hal yang unik dan memiliki unsur penting (news value) untuk disuarakan.

Berdasar pengamatan, maka responden mulai menuangkan hal-hal yang ada dipikirannya, aktifitas ini menjadikan responden mulai berkonfrontasi dengan pikiran dan opininya sendiri. $\mathrm{Ru}-$ tinitasnya ini menjadikan Blogger mengasah kemampuan untuk mengekpresikan diri sebagai upaya dari bagian keinginannya untuk selalu berkomunikasi dengan pihak lain dan mengharapkanfeedback secepatnya. Situasi ini menjadikan Blog memiliki sifat interaktif.

Riset atas penggunaan Blog sebagai medium komunikasi mampu menghasilkan pendekatan atas hadirnya Blog sebagai budaya digital dalam perspektif komunikasi massa. Merujuk pada diskusi yang terus berkembang bahwa sifat interaktifitas Blog yang memiliki distingsi utama dengan media konvensional. Blog memiliki kebalikan struktur dari media konvensional yang bersifat top-down dan cenderung linier. Beberapa ahli sepakat menyuarakan bahwa Blog termasuk kategori contoh evolusi komunitas elektronik yang menunjukkan kemampuan orang secara online menciptakan media yang mereka kostumisasi sendiri. Media yang dikostumisasi sendiri merujuk pada jenis media yang lepas dari kecurigaan media sebagai corong korporasi besar yang sarat atas kekuatan ekonomi politik media.

Upaya riset-riset terdahulu yang berusaha menghadirkan wacana sejauh mana Blog muncul sebagai sebuah media independen atau sekedar trend digital semata menjadi upaya penelusuran ulang dari penelitian ini. Asumsi atas idealisme Blog sebagai medium yang memiliki konsep desentralisasi informasi dan mengembalikan berita di tangan para penggunanya yang tidak dimonopoli oleh sebuah perusahaan media masih menjadi perdebatan. Riset ini menjadi bagian penting dari perdebatan tersebut sebagai bentuk kontribusi akademis dan praktis untuk melihat perkembangan teknologi dalam perspektif komunikasi massa dengan diskusi terbuka yang ilmiah. 


\section{Rekomendasi}

Perlu dikembangkan lagi penelitian seputar konvergensi media dengan berbagai pendekatan varian teori, seperti ekonomi politik media. Hal ini disebabkan telah munculnya komersialisasi Blog melalui penawaran iklan, seperti yang dilakukan oleh Google, Yahoo, Adbrite, Chikita, Text Art Link, dan sebagainya. Akibatnya wilayah publik dalam internet termasuk Blog menjadi area komersil. Ini membuktikan perubahan pola isu desentralisasi informasi menjadi berbasis komodifikasi.

\section{Ucapan Terima Kasih}

Peneliti mengucapkan terimakash kepada Direktorat Jendral Pendidikan Tinggi Departemen Pendidikan Nasional yang telah membiayai penelitian melalaui program hibah Dosen muda. Ucapan terima kasih juga peneliti haturkan kepada Lemaga Penelitian dan Pengabdian Masyarakat UPN "Veteran" Yogyakarta yang telah membantu secara administrasi proses penelitian ini.

\section{Daftar Pustaka}

Allan, Stuart, 2004, News Culture, Glasgow, Bell and Bain.
Eriyanto, 2001, Analisis Wacana; Pengantar Analisis Teks Media, LKiS; Yogyakarta.

Herman, Achmad dan Jimmy Nurdiansa, 2010, Analisis Framing Pemberitaan Konflik Israel-Palestina dalam Harian Kompas dan Radar Sulteng, Jurnal Ilmu Komunikasi UPN "Veteran" Yogyakarta vol 8, No. 2 terakreditasi B.

McQuail, Dennis, 2000, Mass Communication Theory, London, McGraw Hill.

Slamet, Y., 2001, Teknik Pengambilan Sampel untuk Penelitian Kuantitatif dan Kualitatif, Universitas Sebelas Maret , Surakarta.

http//www.yuanita blog. Survey, html, 01 Maret 2007

http//www.enda.Webblog history, html, 01 Maret 2007

"Merriam Webster Dictionary", (online), pada; http://www.m-w.com, 02 Maret 2007

http//www.ath-tahriq.blogspot.com

$\mathrm{http} /$ /www.subhanafifi.blogspot.com

(http://rusydafauzana.multiply.com/journal/item/ 17representasi_kebijakan_pubpil_dalam _pengoperasian_busway_oleh_pemerintah _DKI diunggah 01 Maret 2007) 